\title{
SCIENTIFIC REPORTS

\section{OPEN Probabilistic risk assessment and spatial distribution of potentially toxic elements in groundwater sources in Southwestern Nigeria}

\author{
PraiseGod Chidozie Emenike $\mathbb{1}^{1 *}{ }^{*}$, Imokhai Tenebe ${ }^{2}$, Nkpa Ogarekpe $^{3}$, David Omole ${ }^{1}$ \& \\ Chidozie Nnaji ${ }^{4,5}$
}

The study investigated the concentration of potentially toxic heavy metals (PTHM) in groundwater sources (hand-dug wells and boreholes), spatial distribution, source apportionment, and health risk impact on local inhabitants in Ogun state. One hundred and eight water samples from 36 locations were analysed for $\mathrm{Cr}, \mathrm{Ni}, \mathrm{Pb}, \mathrm{Fe}, \mathrm{Mn}, \mathrm{Mg}$, $\mathrm{Ca}$ and Al. Mean values of $0.013,0.003,0.010,0.088,0.004$ and $3.906 \mathrm{mg} / \mathrm{L}$ were obtained for $\mathrm{Pb}, \mathrm{Cr}, \mathrm{Ni}, \mathrm{Fe}, \mathrm{Mn}$, and $\mathrm{Al}$ respectively at lju district. Meanwhile, the average values of $\mathrm{Pb}, \mathrm{Ni}, \mathrm{Fe}, \mathrm{Mn}$, and $\mathrm{Al}$ concentrations at Atan district were $0.008,0.0023,0.011$, 0.003 , and $1.319 \mathrm{mg} / \mathrm{L}$ respectively. Results also revealed that the $44.4 \%$ and $11.13 \%$ of the borehole and well-water samples surpassed the World Health Organization limits for Pb at Atan. In Iju, the concentration of $\mathrm{Pb}$ and $\mathrm{Al}$ were relatively high, exceeding the stipulated standard in $100 \%$ of the samples. The Multivariate statistical analysis employed produced principal factors that accounted for $78.674 \%$ and $86.753 \%$ of the variance at Atan and lju region respectively. Based on this, PTHM were traced to geogenic sources (weathering, dissolution, leaching) and anthropogenic emissions from industrial activities. In addition, the hazard quotient values obtained from the health risk assessment identified potential non-carcinogenic risk due to $\mathrm{Pb}$ via ingestion route. Ni was found to have high carcinogenic risk on adult and children, having exceeded the threshold limit. The outcome of the carcinogenic risk assessment revealed that $\mathbf{8 8 . 6 7 \%}$ (for adults) and $\mathbf{1 . 1 2 \%}$ (for children) of the cancer risk values surpassed the specified limits at lju, whereas the cancer risk values were considerably lesser at Atan. In conclusion, the report of this study should serve as a beacon that will spark up strategic planning, comprehensive water resource management, and extensive treatment schemes in order to address the health complications linked with environmental pollution.

Global attention has been directed towards environmental deterioration due to the threat it poses to living creatures and standard of living ${ }^{1,2}$. Agricultural activities, industrialisation and urbanisation have emerged as a prime contributor to the rising environmental pollution affecting human lives ${ }^{3-5}$. Observing this, groundwater, which serves as a drinking source in most countries, continue to be polluted with toxic contaminants such as heavy metals (HMs $)^{6,7}$. According to Fallahzadeh et al. ${ }^{8}$ and Khamirchi et al. ${ }^{9}$, poor waste management of waste resulting from industrial and allied process is largely responsible for groundwater contamination observed around the world. Hadley and Newell, ${ }^{10}$ and Chabukdhara et al. ${ }^{11}$ added that the indiscriminate release of industrial waste into the environment could lead to a rise in groundwater contamination.

HMs are classified as toxic because they can penetrate water aquifers and consequently, agglomerate in the food chain ${ }^{12-14}$. It is important to mention that heavy metal toxicity is based on the fact that they are non-biodegradable, persistent, xenobiotic and can accumulate in humans over a time ${ }^{15-18}$. HMs such as chromium $(\mathrm{Cr})$. Copper $(\mathrm{Cu})$ and zinc $(\mathrm{Zn})$ are considered toxic to biota when their thresholds are exceeded ${ }^{19}$.

${ }^{1}$ Department of Civil Engineering, Covenant University, Ota, Ogun State, Nigeria. ${ }^{2}$ Ingram School of Engineering, Ingram School of Engineering, Texas State University, San Marcos, Texas, USA. ${ }^{3}$ Department of Civil Engineering, Cross River University of Technology, Calabar, Nigeria. ${ }^{4}$ Department of Civil Engineering, University of Nigeria, Nsukka, Enugu State, Nigeria. ${ }^{5}$ Faculty of Engineering and Built Environment University of Johannesburg, Johannesburg, South Africa. *email: praiseGod.emenike@covenantuniversity.edu.ng 
Arsenic (As) can cause visceral $\operatorname{cancer}^{20}$ as well as liver, and bladder $\operatorname{cancer}^{21}$. Cadmium (Cd) can cause a decline in cognitive capacity, renal disorder and consequently, bone $\operatorname{loss}^{22-24}$. Lead $(\mathrm{Pb})$ affects the central nervous system (CNS), especially in children, thereby causing hyperactivity, fatigue, anaemia and diminished IQ ${ }^{25-28}$. Furthermore, the nutritional demand of HMs varies considerably between different species and the gap between their optimum concentration are quite low. Thus, exposure to an excess concentration of heavy metal proportions may lead to severe nervous imbalance and possibly death ${ }^{29}$

Considering the adverse health effect and possible death threat posed by HMs on living organism, constant exposure to polluted groundwater sources poses a serious risk to human health. Shankar et al..$^{30}$ reported that groundwater contamination had adverse effect on almost $14 \%$ of the global population. Hence, it is essential to monitor the quality of water consumed in order to safeguard human health, especially those dwelling around industrial regions ${ }^{7}$. Besides, it is crucial to conduct health risk assessment (HRA) for dwellers considering various exposure pathways in line with the recommendations of US EPA ${ }^{31}$. US EPA generated HRA for carcinogens and non-carcinogens after considering the report of the International Agency for Research on Cancer (IARC) relating to the carcinogenic potentials of chemical pesticides ${ }^{31,32}$, and it has been verified to be a vital and effective tool used for water pollution studies ${ }^{11,33-36}$.

Recently, researchers have adopted Monte Carlo Simulation (MCS) technique for the evaluation of hazard potential and pollution risk in different environments ${ }^{8,11,20,37-40}$. MCS quantifies variability and caters for the uncertainties associated with risk assessments ${ }^{41-43}$. The technique works by quantitative estimation of the probability distribution for exposure and health risk analysis ${ }^{44}$. Also, the inclusion of geostatistics to obtain the spatial distribution of contaminants, observe environmental conditions, explain scientific results, and proffer water management solutions have been adopted by several researchers ${ }^{45-50}$. To handle large datasets containing diverse variables, investigators have adopted the use of statistical tools to transform the datasets into factual interpretations useful for general conclusions $\mathrm{s}^{15,33,49,51-53}$

Urban regions in Nigeria have experienced water fluctuations that resulted in the exploitation of groundwater resources (hand-dug wells and boreholes) for industrial, domestic and agricultural purposes. Due to industrialisation and urbanisation, there has been an increase in human activities and the situation has resulted in further pollution of groundwater sources. Major industries around Ado-Odo Ota, Ogun State, Nigeria have exposed dwellers to chronic health conditions traceable to consumption of contaminated groundwater. Kayode et al. ${ }^{54}$ conducted water analysis in neighbouring towns of Ifo, Agbara and Abeokuta and heavy metals and reported a preponderance of heavy metals in the water samples investigated. Other investigators that carried out water analysis within Ado-Odo Ota discovered a similar case ${ }^{55,56}$. However, up till now, there is lack of regional health risk studies despite the growing population within the region engendered by the availability of land, job opportunities (due to the presence of industries), and available market. The stress exerted on water distribution systems have become unbearable due to the rising water demand within the region. Therefore dwellers have resolved to over-exploitation of groundwater reservoirs ${ }^{57}$.

Recently, Emenike et al. ${ }^{17}$ reported the HRA of sachet water sold within Ado-Odo Ota. Meanwhile, Tenebe et al..$^{58}$ reported HRA of surface water within Ado-Odo Ota. However, to the best of our knowledge, there is insufficient literature of previous studies regarding HRA of boreholes and hand-dug wells within the region. Therefore, the objectives of this study focus on the following. First, to evaluate the concentration of HMs in boreholes and hand-dug wells. Second, to investigate the non-carcinogenic and lifetime cancer risk associated with HMs. Third, to determine the spatial distribution of HMs by adopting geospatial technique. Finally, to predict the HMs sources with the aid of statistical tools. Unfortunately, there are no derived guidelines for evaluating risk assessment of contaminants in Nigeria and Africa at large and very few works have considered the use of probabilistic risk assessment on environmental quality indicators within the region. Therefore, it is imperative to state that this study might be the first to conduct a probabilistic estimation of risk exposure within the study region using MCS technique. In addition, Iju and Atan harbours several farmlands and small-medium-enterprises that plays a significant role in the socio-economic advancement of the region. Also, close proximity to the Benin Republic border makes the region an attractive location where industries are located. Therefore, our aim is to ensure that ecotoxicology assessments are included in monitoring schemes-an aspect yet to receive recognition when correspondence relating to contamination are examined in Nigeria.

\section{Materials and Method}

Study area. Iju and Atan are frontline communities situated in Ado-Odo Ota local government area, Ogun state in Southwestern Nigeria (Fig. 1). Atan is located at latitude $6^{\circ} 46^{\prime} 0^{\prime \prime} N$ and longitude $2^{\circ} 48^{\prime} 0^{\prime \prime} E$, whereas Iju is situated between $6^{\circ} 40^{\prime} 0^{\prime \prime} N$ and longitude $3^{\circ} 08^{\prime} 0^{\prime \prime} E$. Both communities lie at the connective route of Nigeria and the Republic of Benin ( $62 \mathrm{~km}$ northeast of Cotonou), and also links directly to the suburb of Sango-Ota township. Both communities are brimming with approximately 146, 000 inhabitants, with a growth rate of $3.5 \%$ annually ${ }^{59}$. The geological characteristics of the region consists of partly complex rock basement of pre-Cambrian formation and partly sedimentary formation, spreading throughout the southwestern part of Nigeria. The vegetation attributes consist of swampy (mangrove and edaphic trees), rainforest and derived forest types ${ }^{60,61}$. For proper analytical reflections, sampling was targeted at locations where water usage is consistent, and the population counts are high.

Sample collection. This study sampled water from boreholes and hand-dug wells that are regularly used by dwellers for drinking and other domestic activities. In total, 108 water samples from 36 locations were analysed. Standard methods for the analysis of water were adopted and necessary precautions were observed. The groundwater sampling protocol outlined by Plazinska et al. ${ }^{62}$ was strictly followed in the collection of water samples from hand-dug wells and boreholes. For each borehole, water was allowed to run for 30 mins before sampling. Whereas in the case of hand-dug wells, dwellers were allowed to collect as much water as they would require before samples 


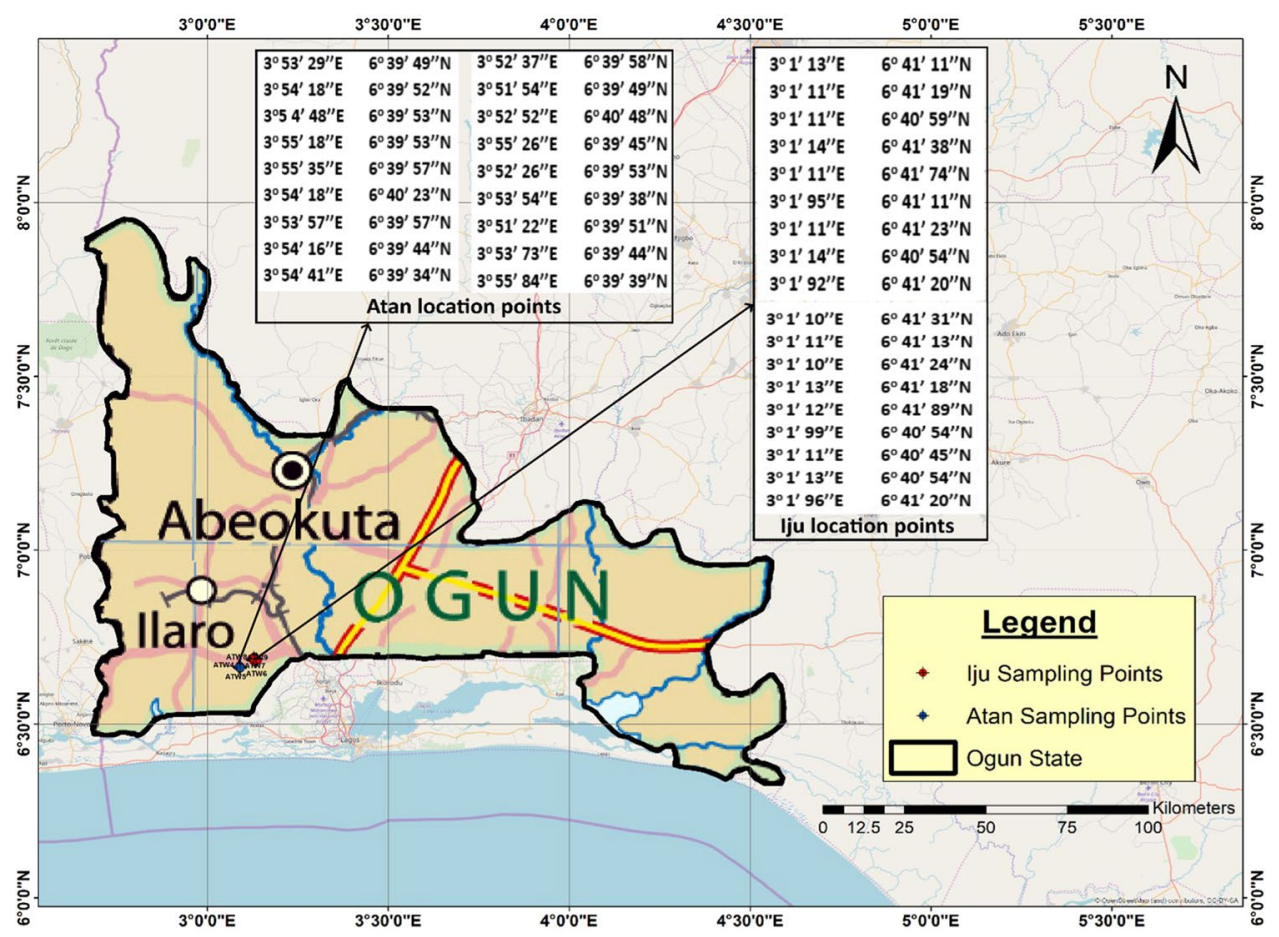

Figure 1. Study area map showing geographic locations of sampling spots.

were obtained with a water sampler. The reason is to ensure that samples collected represent the actual quality of the aquifer (as in the case of boreholes) and that from the casing (as in the case of wells).

Samples collected were transferred to a $100 \mathrm{cl}$ high-density polyethylene (HDPE) bottle. Before this, the HDPE bottles had been washed with phosphate-free detergent, rinsed with $20 \% \mathrm{HNO}_{3}$, followed by deionised water and air dried before taking it to the site. Furthermore, The HDPE bottles were rinsed with the sample water thrice before representative samples were collected. In situ testing were carried out at each sampling point to determine the $\mathrm{pH}$, electrical conductivity (EC), total dissolved solids (TDS) and temperature. It was necessary to measure these water parameters due to their ability to change during transportation. After acquiring the representative samples, a few drops of $5 \% \mathrm{HNO}_{3}$ was added immediately to prevent biological growth and precipitation of metals. Samples were labelled appropriately, placed in an icebox and transported to the laboratory where they were stored in a refrigerator (regulated at $4^{\circ} \mathrm{C}$ ) for further analysis. The heavy metals analysed in the present work were selected in line with the observations of different investigators within nearby towns and regions ${ }^{63-65}$. Sensitive water parameters were measured using a waterproof multiparameter meter (HANNA edge EC/Salinity/ TDS meter HI2030). Heavy metal concentration in the samples was analysed with an atomic absorption spectrophotometer AAS (model AA - 6800) attached to a graphite furnace atomiser (model GFA-EX7) and an autosampler (model ASC - 6100). For each sample, triplicate measurements were carried out, and recalibration was done after analysing nine water samples.

Data analysis. After the laboratory analyses, descriptive statistics and Pearson's Correlation analyses were performed using TIBCO Software Inc. Statistica (data analysis software system), version 13. Furthermore, XLSTAT 2018.5 was used to reduce the dimensionality of the dataset by performing principal factor analysis (PFA). The PFA (Factor loading, scree plot, boxplot, influence plots and loading plots) identifies HM intrusion into the water sources by generating new sets of variables called principal factors (PF). Geospatial analysis (spatial distributions) of HMs considered in this study was performed using ArcMap 10.3.1. Inverse distance weighting (IDW), a type of interpolation technique, was used to create independent raster layers linked with HMs at different points within the study region. This technique has been adopted by investigators to conduct environmental monitoring, understand groundwater chemistry, and to predict pollutant spread ${ }^{20,66-68}$. The principle of the IDW technique centres on data extraction from a subpopulation of the original dataset to develop independent trends.

Quality control. Quality assurance was realized through the application of standard laboratory measures and quality control methods which included replication, standardized adjustments, use of analytical grade chemical blanks and spikes, and following standard operational procedures. Multiparameter instruments were calibrated each time samples are to be taken from each location. Triplicate analyses were adopted throughout, and the mean value recorded per sample. Throughout the metal concentration measurements, standard detection boundaries were observed, and reagent blanks were monitored throughout the analytical process.

Human health risk analysis. Several researchers have adopted the health risk assessment model proposed by the US EPA, ${ }^{69}$ to extensively evaluate the potential risks posed by hazardous chemical substances on 
human health. In the study, HRA of heavy metal concentration was assessed considering two significant pathways through which dwellers are exposed (dermal and ingestion). Ingestion is the most common route, but since the water sources are utilised for other domestic activities, we also considered the dermal route. With respect to the behavioural and physiological variations of different population categories, the exposure risks for adults and children were estimated differently.

Some heavy metals are potential carcinogens while some tend to cause health deterioration when the exposure rates are high. Therefore, we evaluated the carcinogenic and non-carcinogenic risks of specified heavy metal exposure in relation to the allowable threshold concentration outlined by US EPA. To determine the non-carcinogenic risk for ingestion and dermal pathways, the hazard quotients (HQ), which is the ratio of the chronic daily intake $(C D I)$ of individual metals to the oral reference dose $(R f D)$ was calculated using Eq. (1) and Eq. (2) respectively.

$$
\begin{aligned}
H Q_{\text {ingestion }} & =\frac{C D I_{\text {ingestion }}}{R f D_{i}} \\
H Q_{\text {dermal }} & =\frac{C D I_{\text {dermal }}}{R f D_{d}}
\end{aligned}
$$

Where $H Q_{\text {Ingestion }}$ and $H Q_{\text {dermal }}$ represents the hazard proportion via ingestion and dermal exposure pathways respectively, $C D I_{\text {Ingestion }}$ is the chronic daily intake via ingestion route, whereas $C D I_{\text {dermal }}$ is the chronic daily intake via dermal route. $R f D_{i}$ and $R f D_{d}$ are the ingestion and dermal reference dose of HMs respectively. The values of RfD adopted for individual metals are as follows; $1.0 \times 10^{3}\left(\mu \mathrm{g} / \mathrm{kg} \bullet\right.$ day) for $\mathrm{Al}, 1.5 \times 10^{3}(\mu \mathrm{g} / \mathrm{kg} \bullet$ day $)$ for $\mathrm{Cr}$, $7 \times 10^{2}$ for Fe, $1.4 \times 10^{2}(\mu g / k g \bullet$ day $)$ for $\mathrm{Mn}$ and $2.0 \times 10^{1}(\mu g / k g \bullet$ day $)$ for $\mathrm{Ni}^{70}$, and $1.4 \times 10^{2}(\mu g / k g \bullet$ day $)$ for $\mathrm{Pb}^{71}$.

The CDI of HMs via ingestion and dermal routes were estimated in line with US EPA, ${ }^{70}$ recommendation and the expressions are represented in Eq. (3) and Eq. (4) respectively.

$$
\begin{gathered}
C D I_{\text {ingestion }}=\frac{C_{H M W} \times I R_{W} \times E F_{r} \times E D}{B W \times A T_{r}} \\
C D I_{\text {dermal }}=\frac{C_{H M W} \times S A \times K_{p} \times E F_{r} \times E D \times E T \times C F}{B W \times A T_{r}}
\end{gathered}
$$

$C_{H M w}$ is the concentration of HM in water $(\mu \mathrm{g} / \mathrm{L})$; $S A$ represents the exposed skin area $\left(\mathrm{cm}^{2}\right) ; R_{w}$ is the intake rate $\left(L /\right.$ day); $K_{p}$ stands for the coefficient of dermal permeability for water (unitless); $E D$ is the exposure duration (year); $C F$ is the unit conversion factor $\left(L / \mathrm{cm}^{3}\right) ; E T$ is the water exposure time (hours/day); $E F_{r}$ is the resident exposure frequency (days/year); $B W$ is body weight $(\mathrm{kg})$ and $A T_{r}$ is the averaging resident time (days/year).

In the case of carcinogenic risk assessment, we calculated the lifetime cancer risk (LTCR) which can be defined as the likelihood of a person developing cancer throughout a lifetime due to the exposure of a specific metal or mixture of metals. The expression for computing LTCR is outlined in Eq. (5).

$$
L T C R=C D I_{\text {ingestion }} \times S F
$$

where $C D I_{\text {ingestion }}$ is the chronic daily intake of heavy metal through the ingestion pathway and $S F_{H M}$ is the oral slope factor of heavy metal. The slope factor of HMs considered in this study are as follows; $1.7\left(\mathrm{mgkg}^{-1} \mathrm{day}^{-1}\right)$ for $\mathrm{Ni}^{72}, 0.0085\left(\mathrm{mgkg}^{-1} \mathrm{day}^{-1}\right)$ for $\mathrm{Pb}$, and $0.5\left(\mathrm{mgkg}^{-1} \mathrm{day}^{-1}\right)$ for $\mathrm{Cr}$ (extracted from the California Toxicity Criteria database and the Integrated Risk Information System database respectively). The acceptable standard of LTCR values ranges from $10^{-6}$ to $10^{-431}$. Therefore, any value above $10^{-4}$ is considered inadequate or abnormal and could result in cancer over a lifetime. Furthermore, Companion by Minitab (version 5.2.0.0) was used to perform the MCS with 10, 000 iterations. Two population categories (adult and children) were considered, and the results of the simulated exposures for adult and children were expressed at $90^{\text {th }}, 95^{\text {th }}, 99^{\text {th }}$, and $99.9^{\text {th }}$ percentile. The reference value for computing $C D I_{\text {dermal }}$ and $C D I_{\text {ingestion }}$ are listed in the supplementary material (Table $S 1$ ).

\section{Results and Discussion}

Physicochemical and HM characteristics of groundwater sources. Explanatory analysis of the physicochemical parameters of groundwater samples examined in the study is summarised in Table S2a,b. The parameters analysed include aluminium $(\mathrm{Al})$, chromium $(\mathrm{Cr})$, cadmium $(\mathrm{Cd})$, copper $(\mathrm{Cu})$, iron $(\mathrm{Fe})$, manganese $(\mathrm{Mn})$, nickel (Ni), lead (Pb), pH, total dissolved solids (TDS), electrical conductivity (EC), calcium (Ca) and magnesium $(\mathrm{Mg})$, and their concentrations were compared to World Health Organization (WHO) standard ${ }^{73}$ and the Nigerian Standard for Drinking Water Quality (NSDWQ $)^{74}$. The ratio of samples that exceeded the stipulated limits to the total number of samples analysed was used to calculate the percentage violation at each location.

Considering the HM analysed in all groundwater samples in the study region, $\mathrm{Cu}$ and $\mathrm{Cd}$ were not detected. $\mathrm{Cr}$ was not identified at Atan district but was present in well and borehole samples obtained from Iju district. From Table S2a, the $\mathrm{pH}$ value varied from 5.25 to 7.65 (Mean \pm SD; $6.67 \pm 0.577$ ) at Atan district and 2.59 to 7.23 $(5.21 \pm 1.299)$ at Iju district. It is imperative to mention that although $\mathrm{pH}$ has no direct impact on humans, its value influences the solubility of metals and the overall geochemistry of groundwater. According to the results, $100 \%$ of the well water samples obtained at Iju location violated the WHO standard for $\mathrm{pH}$ of drinking water while $55.6 \%$ of the borehole samples were above the limits. At Atan location, $33.33 \%$ and $77.78 \%$ of well-water and borehole samples were within the WHO and NSDWQ pH limits respectively. Woo and $\mathrm{Choi}^{75}$ reported that 
the dissolution of HM from ores could occur at lower $\mathrm{pH}$. Therefore, the low $\mathrm{pH}$ observed at Iju location predicts the identification of $\mathrm{HM}$ at the region.

The mean values of EC observed at Atan $\left(0.2059 \pm 0.0627 \mu \mathrm{Scm}^{-1}\right)$ and Iju $\left(0.7422 \pm 0.3012 \mu \mathrm{Scm}^{-1}\right)$ respectively were below the WHO standard. TDS concentration varied from 163.48 to $773.43 \mathrm{mgL}^{-1}$ (mean value of $440.056 \pm 187.55 \mathrm{mgL}^{-1}$ ) and 152.81 to $782.91 \mathrm{mgL}^{-1}$ (mean value of $451.419 \pm 221.42 \mathrm{mgL}^{-1}$ ) at Atan and Iju district respectively. According to Chabukdhara et al. ${ }^{11}$, increase in TDS could be as a result of fertiliser application, rainwater application, and sediment dissolution. It is important to mention that dwellers within the study region engage in intensive vegetable farming which encourages the application of fertilizers. Despite the disparity in the TDS concentration, WHO standard was not exceeded and no TDS limit has be provided in the NSDWQ report.

HM concentration in groundwater samples obtained from Atan district varied from 0.0018 to $0.0394 \mathrm{mgL}^{-1}$ for $\mathrm{Fe}, 0.001$ to $0.0048 \mathrm{mgL}^{-1}$ for $\mathrm{Mn}, 0.142$ to $2.221 \mathrm{mgL}^{-1}$ for $\mathrm{Al}, 0.0004$ to $0.0053 \mathrm{mgL}^{-1}$ for $\mathrm{Ni}$, and 0.0009 to $0.042 \mathrm{mgL}^{-1}$ for $\mathrm{Pb}$. The results also revealed that the WHO threshold for lead in drinking water was exceeded in $44.44 \%$ of the borehole samples and $11.13 \%$ of the well water samples. Furthermore, WHO and NSDWQ limits for $\mathrm{Al}$ in drinking water were exceeded in $94.44 \%$ of the total samples collected, while the concentration of $\mathrm{Fe}$, $\mathrm{Mn}$, and Ni in drinking water were within the NSDWQ and WHO threshold.

At Iju district (Table S2b), the HM content in the groundwater samples varied from 0.0473 to $0.2397 \mathrm{mgL}^{-1}$ for Fe, 0.0031 to $0.007 \mathrm{mgL}^{-1}$ for $\mathrm{Mn}, 2.031$ to $6.230 \mathrm{mgL}^{-1}$ for $\mathrm{Al}, 0.0021$ to $0.014 \mathrm{mgL}^{-1}$ for $\mathrm{Ni},<0.00001$ to 0.0088 $\mathrm{mgL}^{-1}$ for $\mathrm{Cr}$ and 0.0117 to $0.4272 \mathrm{mgL}^{-1}$ for $\mathrm{Pb}$. In all of these, $100 \%$ of the samples exceeded the NSDWQ and WHO standard values for $\mathrm{Pb}$ and $\mathrm{Al}$ in drinking water, while the concentration of $\mathrm{Ni}, \mathrm{Cr}, \mathrm{Fe}$, and $\mathrm{Mn}$ in the water samples were within the tolerable limits set by the WHO.

Other important water parameters considered are $\mathrm{Ca}$ and $\mathrm{Mg}$, which are indicators of water hardness. $\mathrm{Ca}$ and $\mathrm{Mg}$ concentration varied from 26.144 to $50.433 \mathrm{mgL}^{-1}$ (mean value of $42.328 \mathrm{mgL}^{-1}$ ) and 55.086 to $98.143 \mathrm{mgL}^{-1}$ (mean value of $76.461 \mathrm{mgL}^{-1}$ ) respectively at Atan location. Calcium concentration in all the water samples at Atan location were within the WHO permissible guide. However, 5.56\% of the water samples surpassed the WHO most desirable limit (MDL) of $50 \mathrm{mgL}^{-1}$ for Ca but none exceeded the NSDWQ threshold. Furthermore, $100 \%$ of the water samples exceeded the WHO MDL and NSDWQ of $\mathrm{Mg}$ of $50 \mathrm{mgL}^{-1}$ and $20 \mathrm{mgL}^{-1}$ respectively in drinking water. At Iju district, $\mathrm{Mg}$ and Ca concentration ranged from 45.025 to $90.231 \mathrm{mgL}^{-1}$ (average value of $66.344 \mathrm{mgL}^{-1}$ ) and 56.734 to $219.287 \mathrm{mgL}^{-1}$ (average value of $126.301 \mathrm{mgL}^{-1}$ ). The results also revealed that $27.78 \%$ of the water samples were within the WHO MDL for Ca content in drinking water and $100 \%$ of the samples surpassed the WHO MDL for Mg in drinking water. With respect to the NSDWQ, $44.44 \%$ of the samples surpassed the limit of $\mathrm{Ca}$ in drinking, while $100 \%$ of the samples exceeded the threshold of $\mathrm{Mg}$ in drinking water. The variation identified could be as a result of the dissolution of soil and rock constituents in the water. Also, in as much as Fe content in the water samples were within the WHO guidelines, Magesh et al.$^{67}$ reported that ionic interactions in aquifer could result in the presence of $\mathrm{Fe}$ in the aquifer.

Statistical assessment. Correlation analysis (CA). The chemical characteristics of groundwater can be affected by water recharge, parent rock constituents, and residence time of groundwater the aquifer. However, the degree of participation, level of influence and relationship between water quality parameters can be understood by conducting correlation analysis (CA). The CA of the different water quality parameters at each district produces a correlation matrix that demonstrates the relationship between each parameter. However, to describe the strength of a relationship between the parameters, we adopted a correlation coefficient less than 0.5 as weak, a correlation coefficient ranging from 0.5 to 0.6999 as moderate, and a correlation coefficient of $\geq 0.7$ as strong. Table S3(a) in the supplementary material summarises the correlation coefficients of water quality parameters at Atan district. From the results, a strong positive association exist between $\mathrm{Fe}^{+}$and $\mathrm{Ni}(r=0.9125), \mathrm{Al}$ and $\mathrm{Ni}$ $(r=0.9253), \mathrm{Ni}$ and $\mathrm{Ca}(r=0.8492), \mathrm{Al}$ and $\mathrm{Mn}(r=0.8080), \mathrm{Al}$ and $\mathrm{Fe}(r=0.8083), \mathrm{Al}$ and $\mathrm{Ca}(r=0.8701), \mathrm{Ca}$ and $\mathrm{Mn}(r=0.7449)$ and a moderate positive correlation was observed between Ni and TDS $(r=0.6738), \mathrm{Ni}$ and $\mathrm{Mn}(r=0.6875)$, TDS and $\mathrm{Fe}(r=0.6900)$, $\mathrm{Ca}$ and $\mathrm{Fe}(r=0.6908)$, TDS and $\mathrm{Ca}(r=0.6113)$, TDS and Al $(r=0.6913)$. It is worth mentioning that a strong positive correlation existing between multi-contaminants can be attributed to a common source with which verification can be achieved using principal factor analysis (PFA).

At Iju district, a strong positive correlation was observed between $\mathrm{Fe}$ and $\mathrm{Pb}(r=0.9593)$, $\mathrm{Ca}$ and $\mathrm{Cr}$ $(r=0.9156), \mathrm{Al}$ and $\mathrm{Cr}(r=0.8686)$, TDS and $\mathrm{Cr}(r=0.8495), \mathrm{Ca}$ and $\mathrm{Al}(r=0.8917), \mathrm{Mg}$ and $\mathrm{Al}(r=0.8489)$, TDS and $\mathrm{Ca}(r=0.8407)$, $\mathrm{Ca}$ and $\mathrm{Mg}(r=0.8568), \mathrm{Mg}$ and $\mathrm{Cr}(r=0.8885), \mathrm{Mg}$ and $\mathrm{Pb}(r=0.8222), \mathrm{Cr}$ and $\mathrm{Pb}$ $(r=0.7863), \mathrm{Al}$ and $\mathrm{Pb}(r=0.7580), \mathrm{EC}$ and $\mathrm{Pb}(r=0.7777), \mathrm{Al}$ and TDS $(r=0.7252), \mathrm{Mg}$ and TDS $(r=0.7939)$ (Table S3b). A positive relationship between TDS, $\mathrm{Pb}, \mathrm{Cr}, \mathrm{Al}, \mathrm{EC}, \mathrm{Ca}$ and $\mathrm{Mg}$ suggests that the salinity of the water sources within the district are affected by the aforementioned water quality parameters. Furthermore, moderate positive correlation was observed between $\mathrm{Pb}$ and TDS $(r=0.6785), \mathrm{Pb}$ and $\mathrm{Ca}(r=0.6409), \mathrm{Pb}$ and $\mathrm{Mn}$ $(r=0.5313), \mathrm{Cr}$ and Fe $(r=0.6288), \mathrm{Cr}$ and EC $(r=0.5589), \mathrm{Al}$ and $\mathrm{Fe}(r=0.6046)$, EC and Fe $(r=0.6990), \mathrm{Mg}$ and EC $(r=0.6029)$. In contrast, a strong negative relationship was observed between $\mathrm{pH}$ and $\mathrm{Cr}(r=-0.7102)$, $\mathrm{pH}$ and TDS $(r=-0.7614), \mathrm{pH}$ and $\mathrm{Ca}(r=-0.7723)$, while a moderate negative correlation was recorded between $\mathrm{Mg}$ and $\mathrm{pH}(r=-0.6581), \mathrm{pH}$ and $\mathrm{Al}(r=-0.5414)$. The variation in inter-constituent relationship could be attributed to ion exchange and redox reaction occurring within the groundwater aquifer.

Pollution source identification. Validation of inter-elemental relationship as well as pin-pointing pollutant source was achieved using the PFA tool. The PFA tool decomposes stacked dataset into eigenvalues which in turn provides direction within sample observations characterized by high variability. The analysed variability is linked to the correlated variables to obtain principal factors (PF) that are linearly independent. The PF which serves as a representative of the original variables, are regarded as single observations, with the highest variability in the 


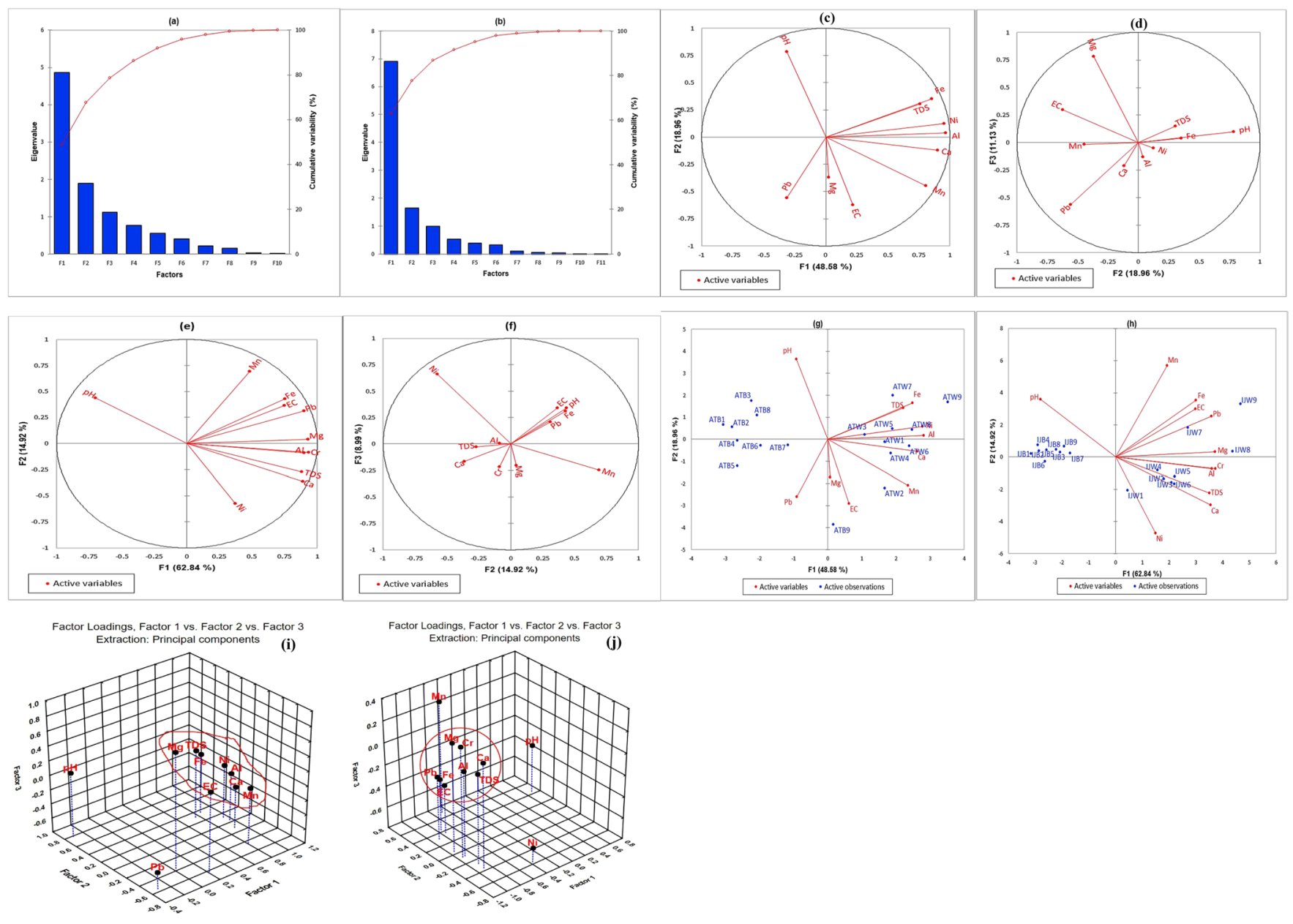

Figure 2. Scree plot of principal components (a) Atan (b) Iju; Factor loading plot of HMs at Atan location showing (c) Factor 1 vs. Factor 2 (d) Factor 2 vs. Factor 3 and at Iju location showing (e) Factor 1 vs. Factor 2 (f) Factor 2 vs. Factor 3; Biplot of HMs distribution and location groupings at (g) Atan considering Factor 1 vs. Factor 2 and (h) Iju considering Factor 1 vs. Factor 2; 3D plot of Factor loadings showing Factor 1 vs. Factor 2 vs. Factor 3 (i) Atan (j) Iju.

observations outlined in the first PF. Other variations unaccounted for in the first PF will, therefore, be listed in the succeeding components.

The results of the PFA produced a scree plot that identified three significant components within the two districts that account for $78.674 \%$ (Atan district) and $86.753 \%$ (Iju district) of the data variability respectively (Fig. 2(a,b)). The components of PF1 and PF2 at Atan district explained 67.54\% of the data variability with PF1 contributing $48.58 \%$ and PF2 contributing $18.96 \%$ of the variability respectively. The combined contributions at PF1 produced a cluster of high positive variables which includes Fe, TDS, Ni, Al, Ca and Mn, whereas PF2 recorded high positive contribution from $\mathrm{pH}$ only (Table S4(a), Fig. 2(c,d)). EC showed high negative loadings in PF2, while Pb showed a slightly moderate negative loading in PF2 Considering the percentage contribution of the aforementioned variables, $\mathrm{Al}(19.212 \%)$ recorded the highest, followed by $\mathrm{Ni}, \mathrm{Ca}, \mathrm{Fe}, \mathrm{Mn}$ and TDS with corresponding values of $18.765 \%, 16.696 \%, 14.994 \%, 13.438 \%$ and $11.879 \%$ respectively. Furthermore, the percentage contribution from pH towards PF2 was observed to be $32.305 \%$ (See Table S4b). It can be suggested that PF1 identifies contamination from both natural and anthropogenic activities. Meanwhile, the presence of TDS, $\mathrm{Al}, \mathrm{Fe}, \mathrm{Mn}$ and $\mathrm{Ca}$ affirms the impact of natural processes such as geological metamorphosis and soil/rock weathering (evaporite, feldspar, schistose). In addition, metals like Fe and Mn could be linked to anthropogenic actions such as electric power generation from fossil fuel, welding, heating and refrigeration, paper mills and power plants. Meanwhile, the presence of $\mathrm{Ni}$ suggests emissions from metal industries, pipe fittings and power plants. Confirmation of the presence of these industries have been outline by Adewumi et al. ${ }^{76}$. However, it is also important to note that geodetic sources such as clay minerals and sandstone could leach Ni into groundwater sources. Nickel content in water is a function of the parent rock formation that makes up the aquifer structure as well as anthropogenic activities. The study region sits on a cretaceous deposition of Palaeocene age, mottled clay, shale, and Palaeocene Ostracods fauna. However, these formations are laden with different Ni concentrations ${ }^{77,78}$. In line with this, combined anthropogenic and geodetic intrusions might be responsible for the presence of $\mathrm{Ni}$ in the groundwater sources ${ }^{79}$. In addition to the source-location identification, the variable cluster of PF1 at 
Atan district get their contributions from well-water sources such as ATW9 (14.139\%), ATW8 (6.977\%), ATW6 (6.563\%), ATW7 (4.144\%) and ATW4 (3.883\%) (Table S4(e) and Fig. 2g). However, the highest contributors to the variable cluster at PF2 include ATB9 (43.564\%) and ATW2 (14.227\%). The well-water sources within the aforementioned location were located close to metallurgy production and vehicle painting industry.

Similarly, the outcome of the PFA conducted at Iju district revealed that two PF (PF1 and PF2) accounted for $77.76 \%$ of the total variation. Therefore, major explanation will focus on PF1 and PF2. PF1 contributed $62.84 \%$ while PF2 added $14.92 \%$ of the total variance (Fig. $2 \mathrm{~b}$ ). PF1 is characterized by significant positive variables such as $\mathrm{Cr}(r=0.936), \mathrm{Mg}(r=0.931), \mathrm{Al}(r=0.900), \mathrm{Pb}(r=0.899), \mathrm{Ca}(r=0.889)$, TDS $(r=0.880), \mathrm{Fe}(r=0.753)$ and EC $(r=0.746)$ (See Table S4(c), Fig. 2(e,f)). Meanwhile, PF2 recorded moderate positive contributions from $\mathrm{Mn}(r=0.692)$, and a weak positive input from $\mathrm{pH}(r=0.439)$. Moderate negative loading was observed for $\mathrm{Ni}$ $(-0.576)$ and a weak negative loading was recorded for TDS and Ca $(-0.273$ and -0.363 respectively).

The order of contributions of various water quality constituents to PF1 can be ranked in decreasing form of $\mathrm{Cr}<\mathrm{Mg}<\mathrm{Al}<\mathrm{Pb}<\mathrm{Ca}<\mathrm{TDS}<\mathrm{Fe}<\mathrm{EC}$ with corresponding values of $12.677 \%, 12.550 \%, 11.729 \%, 11.684 \%$, $11.444 \%, 11.203 \%, 8.202 \%$ and $8.058 \%$ respectively (Table S4d). Considering PF2, Mn contributed 29.211\%, while $\mathrm{pH}$ added $11.713 \%$ to the entire variability. The cluster characterised by $\mathrm{Cr}, \mathrm{Al}, \mathrm{Pb}, \mathrm{TDS}$, Fe and EC suggest anthropogenic sources mainly from industrial activities such as tanneries, galvanising, textiles, pesticides, foundries located in Iju district. Also, the significant negative contribution of $\mathrm{Ni}(20.195 \%)$ signifies that its presence originated from a unique source. To identify the location with the influence attributes mentioned above, the biplot (Fig. 2h) revealed that the well-water sources located at IJW9, IJW8 and IJW7 are laden with high level of $\mathrm{Pb}, \mathrm{Mg}, \mathrm{EC}$ and $\mathrm{Fe}$. Other locations influenced by $\mathrm{Al}, \mathrm{Cr}$, TDS and $\mathrm{Ca}$ include IJW4, IJW2 IJW3, IJW5 and IJW6. To illustrate the combined influence of the first three components at both districts, PF1, PF2 and PF3 were plotted in a $3 \mathrm{D}$ graph (Fig. $2(\mathrm{i}, \mathrm{j})$ )

Comparing the outcome of this study and other works in literature, the mean value of $\mathrm{Pb}$ concentration obtained from Atan district were less than average values reported by Chabukdhara et al. ${ }^{11}$ in Ghaziabad, India; Sirmaur district, India ${ }^{1}$, Costa Rica ${ }^{80}$; Al-Qassim in Saudi Arabia ${ }^{81}$; Durpur and Jallah Jeen in Pakistan ${ }^{82}$, and Pasir Mas in Malaysia ${ }^{83}$, but higher than the mean values of $\mathrm{Pb}$ concentration obtained from Guangxi Zhuang region in China ${ }^{84}$, Shanxi province in China ${ }^{85}$. However, the mean concentration of $\mathrm{Pb}$ recorded at lju were higher than the $\mathrm{Pb}$ concentration obtained in the works mentioned above.

Considering the mean concentration of $\mathrm{Cr}$ obtained in this study, the values recorded at Atan and Iju District were less than the mean values obtained at Durpur and Jallah Jeen in Pakistan ${ }^{82}$, East Singhbhum in India ${ }^{49}$, and Sirmaur district in India ${ }^{1}$. However, the mean values obtained at Iju district were higher than the mean concentration gotten from Yazd Province, Iran ${ }^{20}$, and Southern Peninsular, India ${ }^{67}$.

Mechanisms of heavy metal toxicity. Heavy metals have the ability to replace some cations in water resulting in health toxicity. Lead tends to replace bivalent cations such as $\mathrm{Mg}^{2+}, \mathrm{Ca}^{2+}$ and $\mathrm{Fe}^{2+}$ which in turn, causes harm to the biological mechanisms of cells. The ionic interaction of $\mathrm{Pb}$ in water affects cells adhesion, ionic transportation, protein folding, apoptosis, and cellular signalling ${ }^{86}$. Protein kinase $\mathrm{C}$ which is responsible for memory storage and the regulation of neural excitation is denatured after interaction with $\mathrm{Ca}^{2+87}$. Aluminium disrupts most cellular and physical processes. However, adequate period of Al toxicity has not been allocated because its symptoms can be detected at several intervals after aluminium exposure ${ }^{88}$. Aluminium when consumed, replaces $\mathrm{Fe}^{3+}$ and $\mathrm{Mg}^{2+}$ in the body. The exchange results in several instabilities related with cellular growth, intercellular interaction and secretory functions. These complications share similar degenerative lesions symptoms seen in Alzheimer patients ${ }^{89}$. Iron causes several disruptions in the human body. For example, when $\mathrm{Fe}^{2+}$ fails to bind with proteins in the body, it forms free radicals affecting iron levels in biological fluids and mammalian cells. If ingested in high concentration, $\mathrm{Fe}^{2+}$ becomes corrosive and affects the gastrointestinal tract. Other complications include penetration into the cells of the liver, heart and brain ${ }^{86}$. According to Albretsen ${ }^{90}$, free iron obtained from excessive intake can result in lipid peroxidation which causes damage to the mitochondria and microsomes. Similarly, Grazuleviciene et al..$^{91}$ reported that the hydrogen-free-radicals derived from excessive absorption of iron are responsible for cellular damage, malignant alterations and mutation. Although the health implication of the presence of the identified HMs were not ascertained in the current study, the heightened concentration provides insight on the health toxicity that may arise from ingesting water considering the sources investigated.

Spatial distribution. Figure 3 and Fig. 4 represents the spatial distribution maps of the individual water parameters and heavy metals considered in Atan and Iju district respectively. The spatial analysis for each parameter was plotted separately for each studied district using the IDW technique.

Health risk assessment. Ingestion risk. Computing the exposure risk of metals through different medium is of great importance as it helps to study the toxicity level of water sources to human health. A number of metals were investigated in the study, but detailed attention was given to $\mathrm{Pb}$. It is noteworthy to mention that the $H Q_{\text {ingestion }}$ values of $\mathrm{Al}, \mathrm{Fe}, \mathrm{Mn}$, and $\mathrm{Ni}$ in the borehole samples and $\mathrm{Al}, \mathrm{Fe}, \mathrm{Mn}, \mathrm{Cr}$, and $\mathrm{Ni}$ in the well-water samples at Iju district were below the acceptable standard set by the US EPA. However, the $H Q_{\text {ingestion }}$ computed for $\mathrm{Pb}$ for both sources at Iju district is of great concern and worthy of attention. The probability health risk associated with the metals analysed from the different water sources in this study are highlighted in Table 1 . The computed $H Q_{\text {ingestion }}$ values identified higher risk associated with $\mathrm{Pb}$ at Iju location where the $\mathrm{Pb} H Q_{\text {ingestion }}$ values were above the permissible level for both adult and children $\left(H Q_{\text {ingestion }}>1\right)$. For adult, the mean value of $H Q_{\text {ingestion }}$ for borehole water was 1.108 , while the $90^{\text {th }}, 95^{\text {th }}, 99^{\text {th }}$, and $99.9^{\text {th }}$ percentile were equivalent to $1.753,1.938,2.296$ and 2.632 respectively (Table 1$)$. 

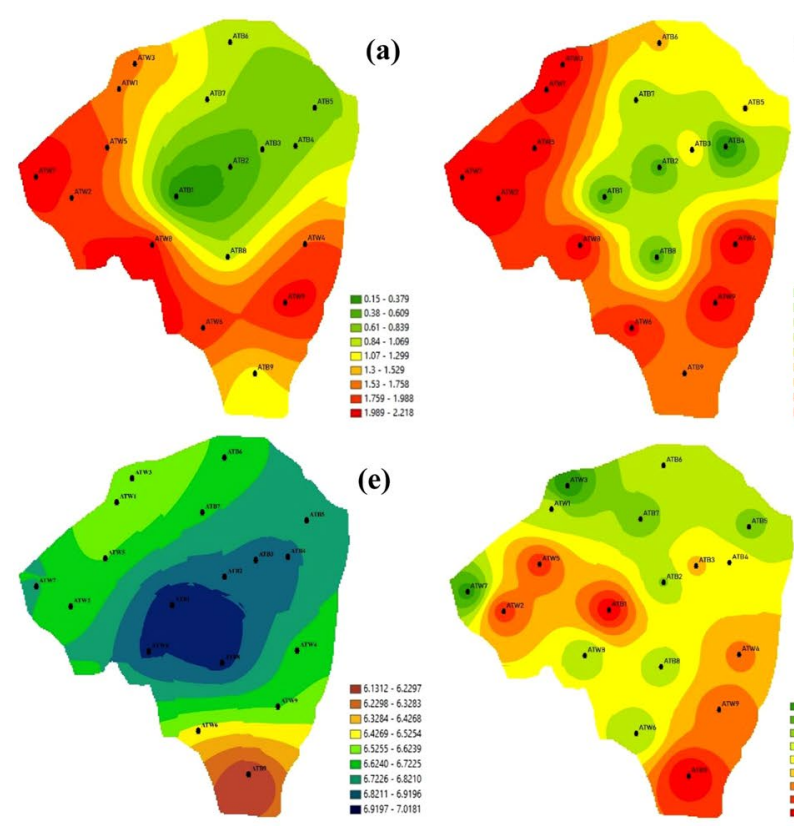

(f)
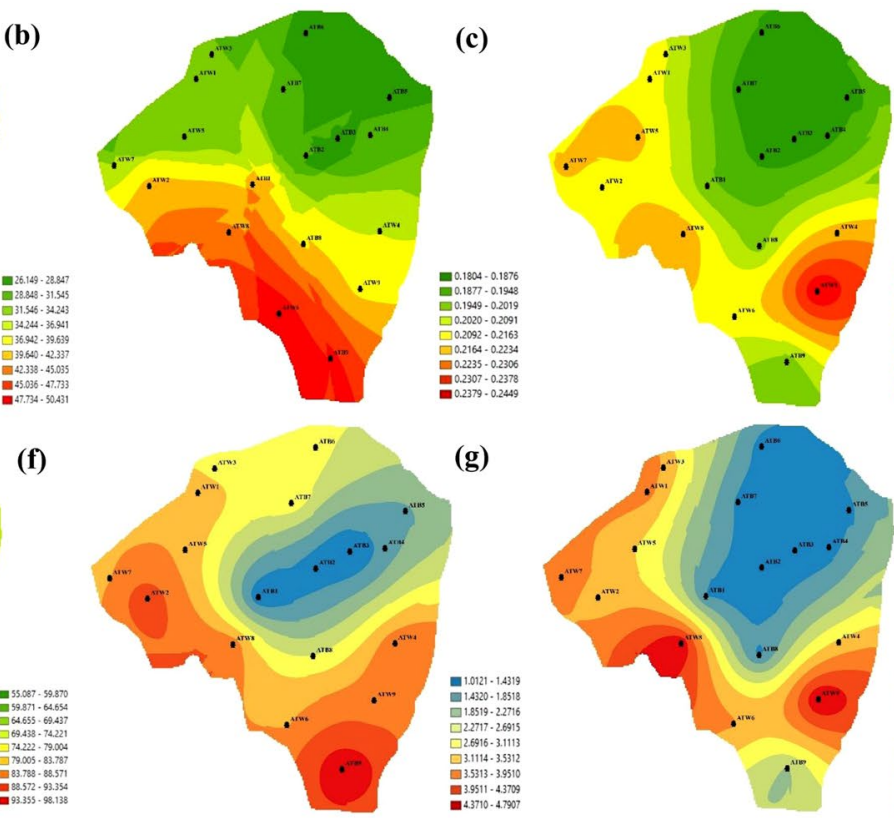

(d)

(g)

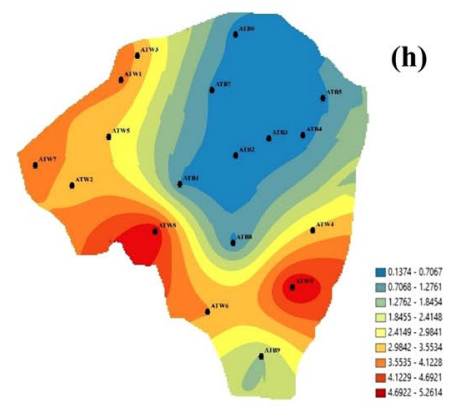

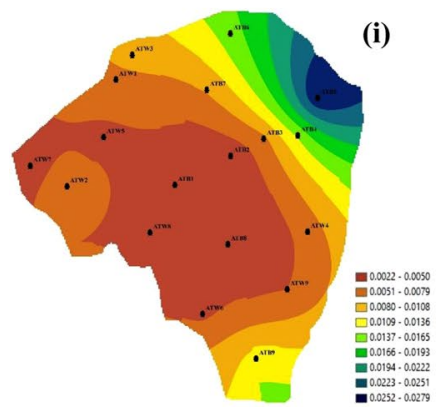

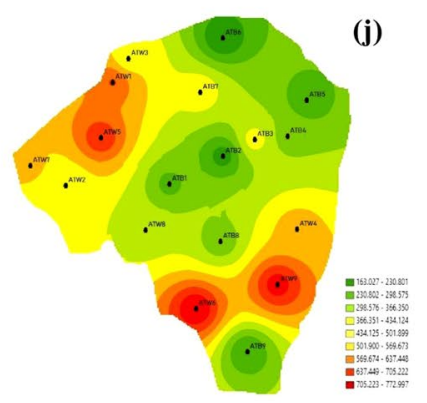

Legend

- Sample locations

Figure 3. Spatial distribution of water parameters considered in Atan Location (a) $\mathrm{Al}$ (b) $\mathrm{Ca}$ (c) EC (d) $\mathrm{Fe}(\mathbf{e})$ $\operatorname{Mg}(\mathbf{f}) \mathrm{Mn}(\mathbf{g}) \mathrm{Ni}(\mathbf{h}) \mathrm{Pb}(\mathbf{i}) \mathrm{pH}(\mathbf{j}) \mathrm{TDS}$.

Further analysis using Monte Carlo simulation revealed that despite the $H Q_{\text {ingestion }}$ of borehole water being greater than 1, only $58.40 \%$ of the simulated values were greater than the US EPA specification (Fig. $5 \mathrm{a}$ ). For children, the mean value of $H Q_{\text {ingestion }}$ for borehole water was 1.864 , while the $90^{\text {th }}, 95^{\text {th }}, 99^{\text {th }}$, and $99.9^{\text {th }}$ percentile were equal to $2.948,3.240,3.828$, and 4.528 respectively. However, the results indicated that $84.78 \%$ of the simulated values surpassed the acceptable limit (Fig. 5b)

Considering the $H Q_{\text {ingestion }}$ of well-water samples at Iju district, the average value of 4.599 and 7.606 were obtained for adult and children respectively. At $90^{\text {th }}, 95^{\text {th }}, 99^{\text {th }}$, and $99.9^{\text {th }}$ percentile, the $H Q_{\text {ingestion }}$ values obtained were 7.750, 8.624, 10.028 and 12.390 respectively for adult, and $H Q_{\text {ingestion }}$ values of 12.970, 14.43, 17.08 and 21.04 respectively for children. Further observation showed that $92.00 \%$ and $94.07 \%$ of the simulated $H Q_{\text {ingestion }}$ values were above the allowable limit for adult and children respectively (Fig. 5c,d).

In the case of Atan district, the health hazard associated with $\mathrm{Al}, \mathrm{Fe}, \mathrm{Pb}, \mathrm{Mn}$, and $\mathrm{Ni}$ were considerably below the allowable limit (less than 1) for both water sources considered in this study. For adults and children, considering borehole consumption, the $H Q_{\text {ingestion }}$ values at $50^{\text {th }}$ percentile for $\mathrm{Pb}$ ingestion were $2.34 \times 10^{-1}$ and $4.088 \times 10^{-1}$ respectively. In a similar vein, the $H Q_{\text {ingestion }}$ for well-water at $50^{\text {th }}$ percentile were $1.049 \times 10^{-1}$ for adult, and $1.755 \times 10^{-1}$ for children. Other inference reveals the absence of health deficiencies to water users at Atan district in relation to the sources investigated in this study. However, the outcome of the investigation extracted from water data at Iju district identifies the need for stringent waste disposal technique and a robust waste management policy for the industries located within the region. These measures are necessary owing to the life-threatening consequences posed by the long-term usage of borehole water and well-water sources within the region. In addition, a potential lead threat has been identified towards adults and children as a result of continuous usage of water from the aforementioned sources. Invariably, children are susceptible to detrimental health consequences, and may not detoxify the exposure by reason of their under-developed body structure. In comparison, the $H Q_{\text {ingestion }}$ values of $\mathrm{Pb}$ at the $50^{\text {th }}$ percentile obtained in the current study were lesser than the values obtained at Igun-Ijesha, Osun State Nigeria ${ }^{92}$, drinking water sources of Dadinkowa dam in Gombe State, Nigeria $^{93}$, water sources consumed in Balogun, Ogun State Nigeria ${ }^{58}$, and water sources of a pipeline vandalised region in Lagos State Nigeria ${ }^{94}$. Furthermore, $H Q_{\text {ingestion }}$ values obtained in the current were higher than the values obtained at water sources of Benin ${ }^{95}$, and surface water sources consumed around Ilesha ${ }^{96}$. 

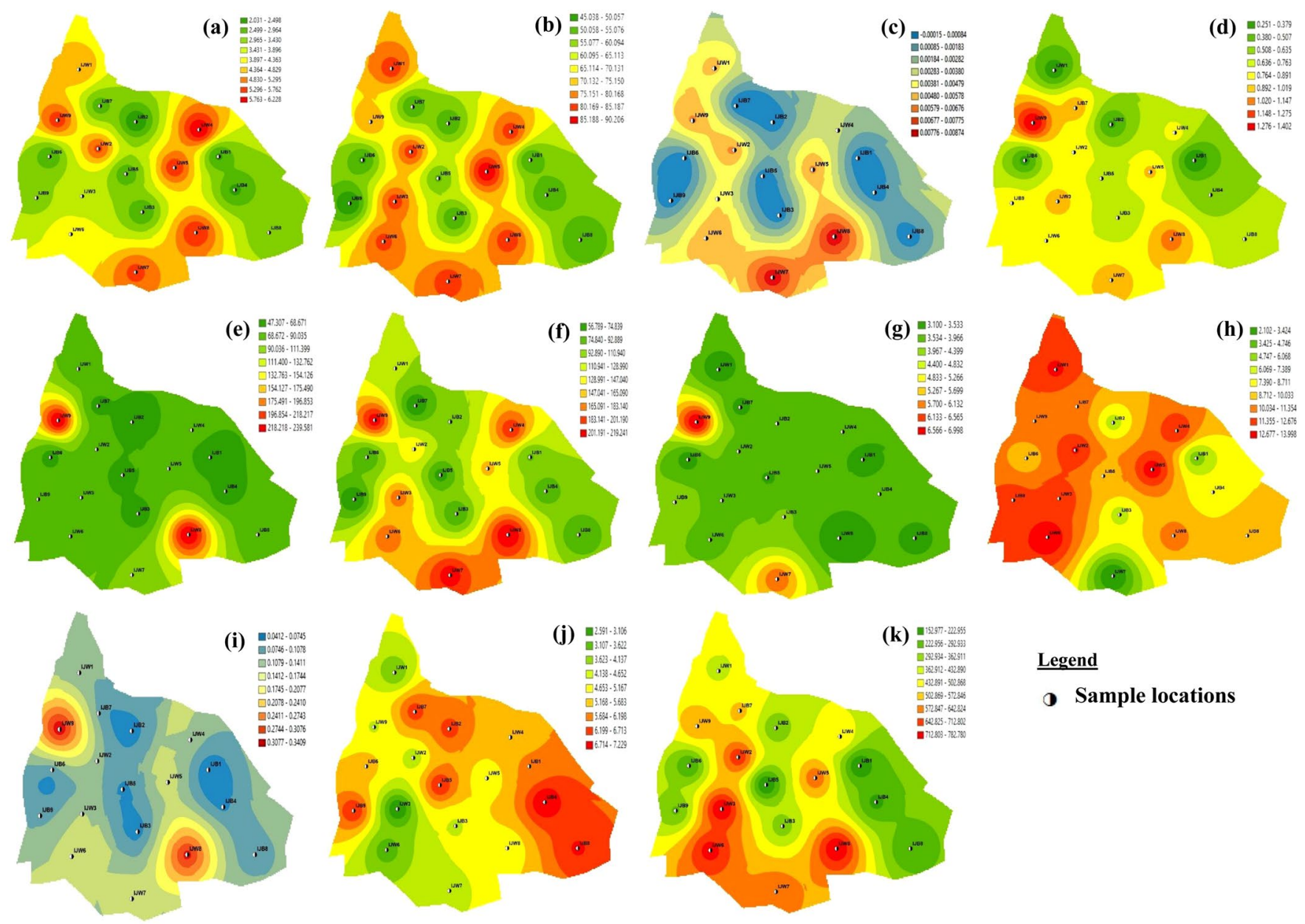

\section{Legend}

- Sample locations

Figure 4. Spatial distribution of water parameters considered in Iju Location (a) $\mathrm{Al}$ (b) $\mathrm{Ca}$ (c) $\mathrm{Cr}(\mathbf{d}) \mathrm{EC}(\mathbf{e}) \mathrm{Fe}$ (f) $\mathrm{Mg}(\mathbf{g}) \mathrm{Mn}(\mathbf{h}) \mathrm{Ni}(\mathbf{i}) \mathrm{Pb}(\mathbf{j}) \mathrm{pH}(\mathbf{k}) \mathrm{TDS}$.

Dermal risk. Table S5,6 shows the dermal probabilistic health risk associated to the HM intake from different sources. The mean $H Q_{\text {dermal }}$ values obtained from borehole and well-water samples at Atan and Iju district were less than the tolerable limit. Therefore, no potential health implication (considering adult and children) is associated with the exposure of HM in water as a result of dermal contact. Furthermore, the $H Q_{\text {dermal }}$ values of all metals considered in this study were below 1 at all levels $\left(50^{\text {th }}, 90^{\text {th }}, 95^{\text {th }}, 99^{\text {th }}\right.$, and $99.9^{\text {th }}$ percentile $)$. This suggests that there is no significant cancer risk that would arise from the use of the groundwater in the study areas for bathing ${ }^{97}$. Reported that the total hazard index (ingestion and dermal contact) of heavy metals in groundwater sampled in Malwa Region of Punjab were below or near 1, which indicated non-carcinogenic health risk from the use of the water. Similar studies have shown that higher carcinogenic and non-carcinogenic risks can be attributed to ingestion pathways ${ }^{98,99}$

Lifetime cancer risk. The prediction of potential lifetime cancer risk (LTCR) for $\mathrm{Pb}, \mathrm{Ni}$ and $\mathrm{Cr}$ were studied at both districts. For well-water sources at Iju district, the average $L T C R_{\text {Child }}$ for $\mathrm{Pb}, \mathrm{Ni}$, and $\mathrm{Cr}$ are $8.157 \times 10^{-7}$, $8.10 \times 10^{-5}$, and $1.30 \times 10^{-5}$ respectively. The $5^{\text {th }}$ and $95^{\text {th }}$ percentile obtained were $7.00 \times 10^{-6}$ and $2.10 \times 10^{-5}$ for $\mathrm{Cr} ; 3.90 \times 10^{-5}$ and $1.24 \times 10^{-4}$ for Ni; $1.547 \times 10^{-7}$ and $1.00 \times 10^{-6}$ for Pb. Similarly, the calculated average $L_{T C R_{\text {Adult }}}$ for $\mathrm{Cr}, \mathrm{Ni}$, and $\mathrm{Pb}$ are $2.70 \times 10^{-5}, 1.63 \times 10^{-4}$ and $2.00 \times 10^{-6}$ respectively. The $5 \%$ and $95 \%$ risk were obtained as $1.50 \times 10^{-5}$ and $4.20 \times 10^{-5}$ for $\mathrm{Cr}$; $7.90 \times 10^{-5}$ and $2.48 \times 10^{-4}$ for Ni; $7.378 \times 10^{-7}$ and $3.00 \times 10^{-6}$ for $\mathrm{Pb}$ (Table 2). Comparing the risk obtained in this study to the maximum allowable risk $\left(1 \times 10^{-4}\right), 89.07 \%$ of the Nickel LTCR values for adults fell outside of the maximum allowable standard and $23.40 \%$ of the Nickel cancer risk values for children exceeded the permissible limits (Fig. 5e,f). These results suggest that cancer risk is higher in adults than in children in the study areas. This is contrary to the findings of Taiyuan, China where it was reported that cancer risk due to ingestion was higher in children than in adults ${ }^{100}$.

In the case of borehole water sources at Iju, the LTCR values for $\mathrm{Cr}$ was not modelled as the concentration was below the detection limit. However, the average cancer risk for Ni was $6.50 \times 10^{-5}$ and $1.37 \times 10^{-4}$ for children and adult respectively. The mean cancer risk calculated for Pb equalled to $2.00 \times 10^{-6}$ for children, and $4.00 \times 10^{-6}$ for adult. Further analysis revealed that $1.12 \%$ of the Nickel LTCR values for children surpassed the specification limits, while $88.67 \%$ of the cancer risk values for adult were above the stipulated standard (Fig. $5 \mathrm{~g}$,h). 


\begin{tabular}{|c|c|c|c|c|c|c|c|c|c|c|c|c|}
\hline \multicolumn{7}{|c|}{ HQ (Adult) } & \multicolumn{6}{|l|}{ HQ (Child) } \\
\hline \multicolumn{13}{|c|}{ Ingestion probabilistic health risk for boreholes locations in Iju } \\
\hline Metals & Mean & SD & \begin{tabular}{|l|} 
90th \\
Percentile
\end{tabular} & \begin{tabular}{|l|} 
95th \\
Percentile
\end{tabular} & $\begin{array}{l}\text { 99th } \\
\text { Percentile }\end{array}$ & \begin{tabular}{|l|} 
99.9th \\
Percentile
\end{tabular} & Mean & SD & $\begin{array}{l}\text { 90th } \\
\text { Percentile }\end{array}$ & \begin{tabular}{|l|} 
95th \\
Percentile
\end{tabular} & $\begin{array}{l}\text { 99th } \\
\text { Percentile }\end{array}$ & \begin{tabular}{|l|} 
99.9th \\
Percentile
\end{tabular} \\
\hline $\mathrm{Al}$ & $7.792 \mathrm{E}-02$ & $1.030 \mathrm{E}-02$ & $9.121 \mathrm{E}-02$ & $9.502 \mathrm{E}-02$ & 1.017E-01 & $1.102 \mathrm{E}-01$ & $1.317 \mathrm{E}-01$ & $1.743 \mathrm{E}-02$ & $1.540 \mathrm{E}-01$ & $1.605 \mathrm{E}-01$ & $1.723 \mathrm{E}-01$ & $1.851 \mathrm{E}-01$ \\
\hline $\mathrm{Cd}$ & ND & ND & $\mathrm{ND}$ & ND & $\mathrm{ND}$ & ND & ND & ND & ND & ND & $\mathrm{ND}$ & ND \\
\hline $\mathrm{Fe}$ & $5.948 \mathrm{E}-03$ & $9.070 \mathrm{E}-04$ & 7.119E-03 & 7.438E-03 & 8.019E-03 & $8.767 \mathrm{E}-03$ & $1.002 \mathrm{E}-02$ & $1.542 \mathrm{E}-03$ & $1.199 \mathrm{E}-02$ & $1.254 \mathrm{E}-02$ & $1.368 \mathrm{E}-02$ & $1.498 \mathrm{E}-02$ \\
\hline $\mathrm{Pb}$ & $1.108 \mathrm{E}+00$ & $5.040 \mathrm{E}-01$ & $1.753 \mathrm{E}+00$ & $1.938 \mathrm{E}+00$ & $2.296 \mathrm{E}+00$ & $2.632 \mathrm{E}+00$ & $1.864 \mathrm{E}+00$ & 8.389E-01 & $2.948 \mathrm{E}+00$ & $3.240 \mathrm{E}+00$ & $3.828 \mathrm{E}+00$ & $4.528 \mathrm{E}+00$ \\
\hline $\mathrm{Cu}$ & ND & ND & ND & ND & ND & ND & ND & ND & ND & ND & ND & ND \\
\hline $\mathrm{Mn}$ & $5.433 \mathrm{E}-03$ & $4.500 \mathrm{E}-04$ & $6.007 \mathrm{E}-03$ & $6.174 \mathrm{E}-03$ & $6.476 \mathrm{E}-03$ & $6.793 \mathrm{E}-03$ & $9.158 \mathrm{E}-03$ & $7.600 \mathrm{E}-04$ & $1.013 \mathrm{E}-02$ & $1.040 \mathrm{E}-02$ & $1.092 \mathrm{E}-02$ & $1.153 \mathrm{E}-02$ \\
\hline $\mathrm{Cr}$ & $\mathrm{ND}$ & $\mathrm{ND}$ & $\mathrm{ND}$ & $\mathrm{ND}$ & $\mathrm{ND}$ & $\mathrm{ND}$ & $\mathrm{ND}$ & $\mathrm{ND}$ & $\mathrm{ND}$ & $\mathrm{ND}$ & $\mathrm{ND}$ & ND \\
\hline $\mathrm{Ni}$ & $1.282 \mathrm{E}-02$ & 3.157E-03 & $1.689 \mathrm{E}-02$ & $1.804 \mathrm{E}-02$ & $2.015 \mathrm{E}-02$ & $2.312 \mathrm{E}-02$ & $2.171 \mathrm{E}-02$ & $5.357 \mathrm{E}-03$ & $2.860 \mathrm{E}-02$ & $3.044 \mathrm{E}-02$ & $3.427 \mathrm{E}-02$ & $3.738 \mathrm{E}-02$ \\
\hline \multicolumn{13}{|c|}{ Ingestion probabilistic health risk for water wells locations in Iju } \\
\hline $\mathrm{Al}$ & $1.117 \mathrm{E}-01$ & $9.990 \mathrm{E}-03$ & $1.244 \mathrm{E}-01$ & $1.280 \mathrm{E}-01$ & $1.352 \mathrm{E}-01$ & $1.434 \mathrm{E}-01$ & $1.887 \mathrm{E}-01$ & $1.652 \mathrm{E}-02$ & $2.098 \mathrm{E}-01$ & $2.159 \mathrm{E}-01$ & $2.273 \mathrm{E}-01$ & $2.428 \mathrm{E}-01$ \\
\hline $\mathrm{Cd}$ & $\mathrm{ND}$ & ND & ND & ND & $\mathrm{ND}$ & ND & $\mathrm{ND}$ & $\mathrm{ND}$ & $\mathrm{ND}$ & $\mathrm{ND}$ & $\mathrm{ND}$ & $\mathrm{ND}$ \\
\hline $\mathrm{Fe}$ & $1.160 \mathrm{E}-02$ & 7.011E-03 & $2.057 \mathrm{E}-02$ & $2.313 \mathrm{E}-02$ & 2.817E-02 & $3.336 \mathrm{E}-02$ & $1.960 \mathrm{E}-02$ & $1.187 \mathrm{E}-02$ & $3.496 \mathrm{E}-02$ & $3.925 \mathrm{E}-02$ & $4.701 \mathrm{E}-02$ & 5.578E-02 \\
\hline $\mathrm{Pb}$ & $4.559 \mathrm{E}+00$ & $2.499 \mathrm{E}+00$ & $7.750 \mathrm{E}+00$ & $8.624 \mathrm{E}+00$ & $1.028 \mathrm{E}+01$ & $1.239 \mathrm{E}+01$ & $7.606 \mathrm{E}+00$ & $4.200 \mathrm{E}+00$ & $1.297 \mathrm{E}+01$ & $1.443 \mathrm{E}+01$ & $1.708 \mathrm{E}+01$ & $2.104 \mathrm{E}+01$ \\
\hline $\mathrm{Cu}$ & $\mathrm{ND}$ & ND & ND & ND & ND & ND & ND & ND & ND & ND & ND & ND \\
\hline $\mathrm{Mn}$ & $6.362 \mathrm{E}-03$ & $1.989 \mathrm{E}-03$ & $8.934 \mathrm{E}-03$ & $9.630 \mathrm{E}-03$ & $1.097 \mathrm{E}-02$ & $1.250 \mathrm{E}-02$ & $1.077 \mathrm{E}-02$ & $3.348 \mathrm{E}-03$ & $1.508 \mathrm{E}-02$ & $1.625 \mathrm{E}-02$ & $1.857 \mathrm{E}-02$ & $2.103 \mathrm{E}-02$ \\
\hline $\mathrm{Cr}$ & $6.057 \mathrm{E}-02$ & $1.813 \mathrm{E}-02$ & $8.384 \mathrm{E}-02$ & 9.049E-02 & $1.031 \mathrm{E}-01$ & $1.156 \mathrm{E}-01$ & $1.024 \mathrm{E}-01$ & $3.068 \mathrm{E}-02$ & $1.421 \mathrm{E}-01$ & $1.529 \mathrm{E}-01$ & $1.736 \mathrm{E}-01$ & $1.994 \mathrm{E}-01$ \\
\hline $\mathrm{Ni}$ & $1.694 \mathrm{E}-02$ & 5.401E-03 & $2.375 \mathrm{E}-02$ & $2.592 \mathrm{E}-02$ & $2.971 \mathrm{E}-02$ & $3.444 \mathrm{E}-02$ & $2.850 \mathrm{E}-02$ & 9.103E-03 & $4.008 \mathrm{E}-02$ & $4.357 \mathrm{E}-02$ & $4.958 \mathrm{E}-02$ & $5.683 \mathrm{E}-02$ \\
\hline \multicolumn{13}{|c|}{ Ingestion probabilistic health risk for boreholes locations in Atan } \\
\hline $\mathrm{Al}$ & $2.220 \mathrm{E}-02$ & $9.650 \mathrm{E}-03$ & $3.472 \mathrm{E}-02$ & $3.814 \mathrm{E}-02$ & $4.472 \mathrm{E}-02$ & $5.341 \mathrm{E}-02$ & $3.720 \mathrm{E}-02$ & $1.641 \mathrm{E}-02$ & $5.818 \mathrm{E}-02$ & $6.426 \mathrm{E}-02$ & $7.562 \mathrm{E}-02$ & $8.837 \mathrm{E}-02$ \\
\hline $\mathrm{Cd}$ & ND & ND & ND & ND & $\mathrm{ND}$ & ND & $\mathrm{ND}$ & ND & $\mathrm{ND}$ & $\mathrm{ND}$ & $\mathrm{ND}$ & ND \\
\hline $\mathrm{Fe}$ & $3.130 \mathrm{E}-04$ & $1.220 \mathrm{E}-04$ & $4.690 \mathrm{E}-04$ & $5.130 \mathrm{E}-04$ & $5.970 \mathrm{E}-04$ & $6.840 \mathrm{E}-04$ & $5.290 \mathrm{E}-04$ & $2.100 \mathrm{E}-04$ & $7.980 \mathrm{E}-04$ & $8.800 \mathrm{E}-04$ & $1.020 \mathrm{E}-03$ & $1.171 \mathrm{E}-03$ \\
\hline $\mathrm{Pb}$ & $2.347 \mathrm{E}-01$ & $2.849 \mathrm{E}-01$ & $5.978 \mathrm{E}-01$ & $7.061 \mathrm{E}-01$ & $8.924 \mathrm{E}-01$ & $1.098 \mathrm{E}+00$ & $4.088 \mathrm{E}-01$ & $4.646 \mathrm{E}-01$ & $1.010 \mathrm{E}+00$ & $1.182 \mathrm{E}+00$ & $1.485 \mathrm{E}+00$ & $1.830 \mathrm{E}+00$ \\
\hline $\mathrm{Cu}$ & $\mathrm{ND}$ & ND & ND & ND & ND & ND & ND & ND & ND & ND & $\mathrm{ND}$ & ND \\
\hline $\mathrm{Mn}$ & $3.349 \mathrm{E}-03$ & $1.837 \mathrm{E}-03$ & $5.702 \mathrm{E}-03$ & $6.413 \mathrm{E}-03$ & 7.723E-03 & 9.186E-03 & $5.655 \mathrm{E}-03$ & $3.085 \mathrm{E}-03$ & $9.595 \mathrm{E}-03$ & $1.072 \mathrm{E}-02$ & $1.288 \mathrm{E}-02$ & $1.487 \mathrm{E}-02$ \\
\hline $\mathrm{Cr}$ & $\mathrm{ND}$ & ND & $\mathrm{ND}$ & ND & $\mathrm{ND}$ & $\mathrm{ND}$ & $\mathrm{ND}$ & ND & $\mathrm{ND}$ & $\mathrm{ND}$ & $\mathrm{ND}$ & $\mathrm{ND}$ \\
\hline $\mathrm{Ni}$ & $1.018 \mathrm{E}-03$ & 6.460E-04 & $1.842 \mathrm{E}-03$ & $2.091 \mathrm{E}-03$ & $2.534 \mathrm{E}-03$ & $2.991 \mathrm{E}-03$ & $1.728 \mathrm{E}-03$ & $1.094 \mathrm{E}-03$ & $3.122 \mathrm{E}-03$ & $3.515 \mathrm{E}-03$ & $4.268 \mathrm{E}-03$ & $5.141 \mathrm{E}-03$ \\
\hline \multicolumn{13}{|c|}{ Ingestion probabilistic health risk for water wells locations in Atan } \\
\hline $\mathrm{Al}$ & $5.682 \mathrm{E}-02$ & 7.146E-03 & $6.588 \mathrm{E}-02$ & $6.863 \mathrm{E}-02$ & $7.361 \mathrm{E}-02$ & $7.951 \mathrm{E}-02$ & $9.591 \mathrm{E}-02$ & $1.197 \mathrm{E}-02$ & $1.114 \mathrm{E}-01$ & $1.154 \mathrm{E}-01$ & $1.236 \mathrm{E}-01$ & $1.328 \mathrm{E}-01$ \\
\hline $\mathrm{Cd}$ & ND & ND & ND & ND & ND & ND & ND & $\mathrm{ND}$ & ND & ND & ND & ND \\
\hline $\mathrm{Fe}$ & $1.968 \mathrm{E}-03$ & $8.550 \mathrm{E}-04$ & $3.056 \mathrm{E}-03$ & $3.364 \mathrm{E}-03$ & $3.955 \mathrm{E}-03$ & $4.659 \mathrm{E}-03$ & $3.293 \mathrm{E}-03$ & $1.450 \mathrm{E}-03$ & $5.161 \mathrm{E}-03$ & $5.698 \mathrm{E}-03$ & $6.664 \mathrm{E}-03$ & $7.765 \mathrm{E}-03$ \\
\hline $\mathrm{Pb}$ & $1.049 \mathrm{E}-01$ & $7.969 \mathrm{E}-02$ & $2.061 \mathrm{E}-01$ & $2.363 \mathrm{E}-01$ & $2.935 \mathrm{E}-01$ & $3.594 \mathrm{E}-01$ & $1.755 \mathrm{E}-01$ & $1.326 \mathrm{E}-01$ & $3.434 \mathrm{E}-01$ & $3.903 \mathrm{E}-01$ & $4.786 \mathrm{E}-01$ & $5.916 \mathrm{E}-01$ \\
\hline $\mathrm{Cu}$ & $\mathrm{ND}$ & $\mathrm{ND}$ & ND & ND & $\mathrm{ND}$ & $\mathrm{ND}$ & ND & $\mathrm{ND}$ & $\mathrm{ND}$ & $\mathrm{ND}$ & $\mathrm{ND}$ & ND \\
\hline $\mathrm{Mn}$ & $5.391 \mathrm{E}-03$ & $5.490 \mathrm{E}-04$ & $6.079 \mathrm{E}-03$ & $6.297 \mathrm{E}-03$ & $6.703 \mathrm{E}-03$ & $7.108 \mathrm{E}-03$ & $9.096 \mathrm{E}-03$ & $9.060 \mathrm{E}-04$ & $1.025 \mathrm{E}-02$ & $1.059 \mathrm{E}-02$ & $1.120 \mathrm{E}-02$ & $1.193 \mathrm{E}-02$ \\
\hline $\mathrm{Cr}$ & $\mathrm{ND}$ & $\mathrm{ND}$ & $\mathrm{ND}$ & $\mathrm{ND}$ & $\mathrm{ND}$ & $\mathrm{ND}$ & $\mathrm{ND}$ & $\mathrm{ND}$ & $\mathrm{ND}$ & $\mathrm{ND}$ & $\mathrm{ND}$ & $\mathrm{ND}$ \\
\hline $\mathrm{Ni}$ & $5.806 \mathrm{E}-03$ & $1.292 \mathrm{E}-03$ & $7.455 \mathrm{E}-03$ & $7.929 \mathrm{E}-03$ & $8.836 \mathrm{E}-03$ & $9.922 \mathrm{E}-03$ & $9.756 \mathrm{E}-03$ & $2.157 \mathrm{E}-03$ & $1.251 \mathrm{E}-02$ & $1.329 \mathrm{E}-02$ & $1.492 \mathrm{E}-02$ & $1.640 \mathrm{E}-02$ \\
\hline
\end{tabular}

Table 1. Ingestion probabilistic health risk for boreholes and water wells in Iju and Atan.

LTCR analysis conducted for the HMs in well-water samples from Atan location indicated that the mean LTCR for Ni was $2.80 \times 10^{-5}$ for children and $5.60 \times 10^{-5}$ for adult. LTCR for Pb recorded a mean value of $1.626 \times 10^{-7}$ for children and $3.289 \times 10^{-7}$ for adult. However, these values were below the maximum permissible standard by the WHO. Similar scenario was observed for borehole water samples as the LTCR values were found to be below the stipulated standard (See Table 2).

An investigation by Koki et al. ${ }^{53}$ revealed that the LTCR for adults were higher when matched with children after long-term exposure to the groundwater in Klang valley and Melaka, Malaysia. Fallahzadeh et al. ${ }^{20}$ reported high carcinogenic risk for lead in groundwater samples in Ardakan, and a high risk for Nickel in groundwater samples in Meibod and Bahabad.

Sensitivity analysis. This study also performed sensitivity analysis to understand how input variables contribute to the probabilistic cancer risk assessment. The results indicated positive influential contribution from the input variables in order of Concentration $>E F>I R>E D$ for lead and Nickel in Atan. In comparison, the impact of the variables on the risk estimation was prominent in Nickel than lead. However, BW had a negative impact on the LTCR calculation for both metals in Atan district (See Fig. S1(a,b). At Iju, the sensitivity analysis revealed concentration as the highest contributor $(40.7 \%$ and $53.3 \%$ for lead and nickel respectively), followed by IR (15.1\% and $12.2 \%$ for lead and nickel respectively), AT (6.8\% and 5.6\% for lead and nickel respectively), EF (2.2\% and $3.8 \%$ for lead and nickel respectively), and a negative influence from BW $(-34.2 \%$ and $-25.1 \%$ for lead and nickel respectively) (Fig. S1(c,d) in supplementary file). 

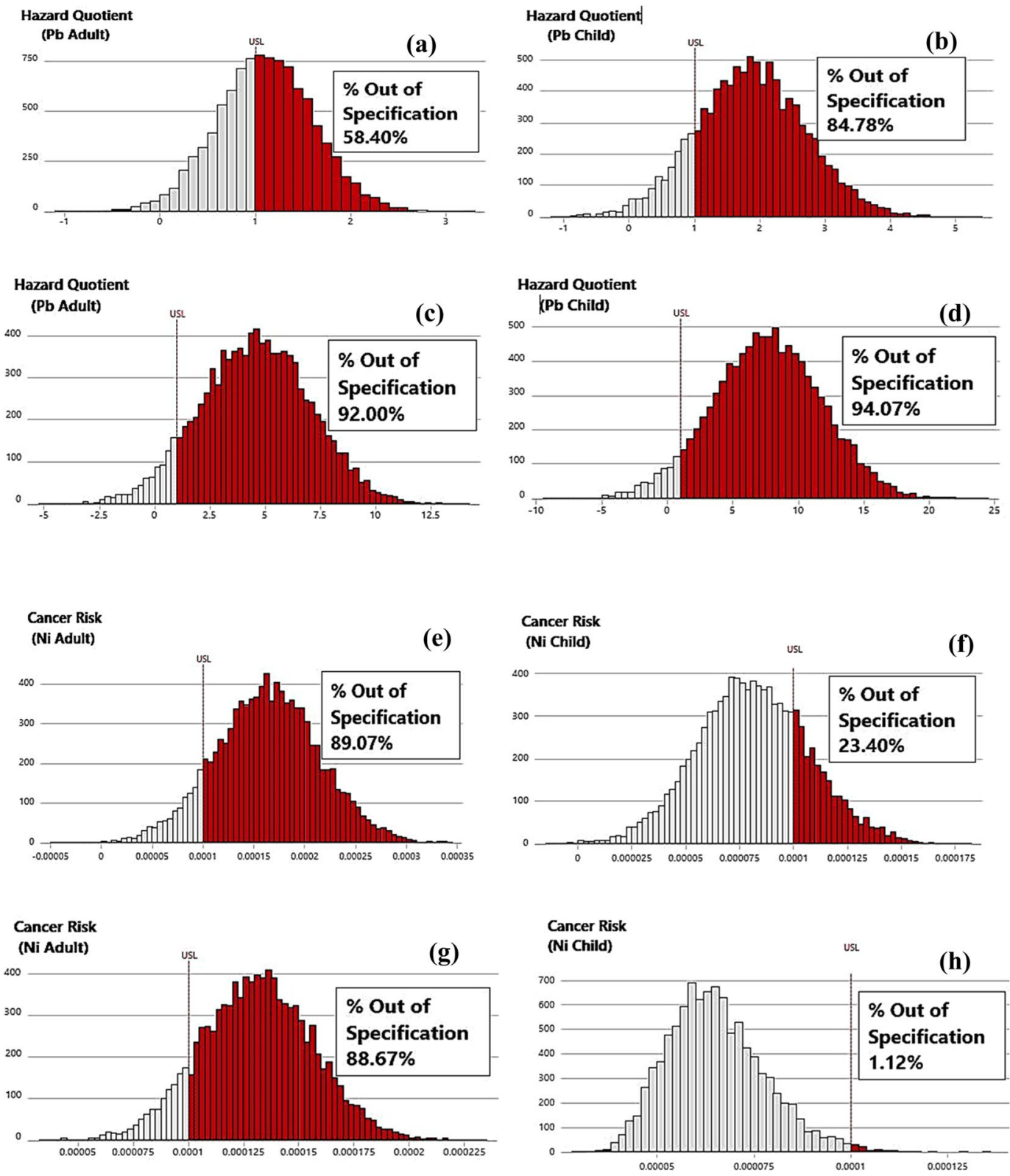

Figure 5. Predicted $\mathrm{HQ}_{\text {ingestion }}$ associated with $\mathrm{Pb}$ in Borehole water for (a) adult (b) child at Iju district, and well-water for (c) adult (d) child at Iju district Predicted $\mathrm{HQ}_{\text {ingestion }}$ associated with $\mathrm{Ni}$ in Borehole water for (e) adult (f) child at Iju district, and well-water for (g) adult (h) child at Iju district.

Regardless of the results obtained from the water quality analysis considering the few water parameters analysed and low number of samples collected, this study reveals a fraction of the environmental risk inhabitants are constantly exposed to. Therefore, the current study should be taken as preliminary.

Uncertainty analysis. In the present study, Monte Carlo Simulation (MCS) approach adopted entails the input of random range of values for each parameter in the estimation of the exposure risk at each site. The population group considered were obtained through a large number of simulations $(10,000)$ in order to derive predictive quantities as the output. Estimating potential health risk in this regard, depends on distribution-based approach rather than deterministic risk estimation approach (point-based calculation) to obtain the probabilistic output at each site. Therefore, the MCS technique integrates variabilities and uncertainties in the risk calculations. However, for accurate estimation of the risk assessment (in the field and during simulation), several uncertainties were considered. First, the sampling points investigated were selected in the region of high population density to describe the study region. Second, accuracy of HM concentration assessment was achieved by taking into consideration, several precautionary measures associated with sample extraction, transportation and storage, quality assurance and control steps reported in earlier sections, and the use of standardized equipment in the laboratory. Third, the input and output parameters were quantified mathematically using probabilistic distributions which 


\begin{tabular}{|l|l|l|l|l|l|l|}
\hline LTCR Child & LTCR ADULT \\
\hline LTCR associated with HMs in well-water at Iju \\
\hline Metals & Mean & $\mathbf{5}^{\text {th }}$ Percentile & $\mathbf{9 5}^{\text {th }}$ Percentile & Mean & $\mathbf{5}^{\text {th }}$ Percentile & $\mathbf{9 5}^{\text {th }}$ Percentile \\
\hline $\mathrm{Cr}$ & 0.000013 & 0.000007 & 0.000021 & 0.000027 & 0.000015 & 0.000042 \\
\hline $\mathrm{Ni}$ & 0.000081 & 0.000039 & 0.000124 & 0.000163 & 0.000079 & 0.000248 \\
\hline $\mathrm{Pb}$ & $8.157 \mathrm{E}-7$ & $1.547 \mathrm{E}-7$ & 0.000001 & 0.000002 & $7.378 \mathrm{E}-7$ & 0.000003 \\
\hline LTCR associated with HMs in borehole water at Iju \\
\hline $\mathrm{Cr}$ & ND & ND & ND & ND & ND & ND \\
\hline $\mathrm{Ni}$ & 0.000065 & 0.000047 & 0.000088 & 0.000131 & 0.000089 & 0.000173 \\
\hline $\mathrm{Pb}$ & 0.000002 & $9.847 \mathrm{E}-7$ & 0.000003 & 0.000004 & 0.000002 & 0.000006 \\
\hline $\mathrm{LTCR}$ associated with HMs in well-water at Atan & \\
\hline $\mathrm{Cr}$ & ND & ND & ND & ND & ND & ND \\
\hline $\mathrm{Ni}$ & 0.000028 & 0.00002 & 0.000039 & 0.000056 & 0.000039 & 0.000078 \\
\hline $\mathrm{Pb}$ & $1.626 \mathrm{E}-7$ & $-4.457 \mathrm{E}-8$ & $3.675 \mathrm{E}-7$ & $3.289 \mathrm{E}-7$ & $-9.263 \mathrm{E}-8$ & $7.484 \mathrm{E}-7$ \\
\hline $\mathrm{LTCR}$ associated with $\mathrm{HMs}$ in borehole water at Iju & \\
\hline $\mathrm{Cr}$ & ND & ND & ND & ND & ND & ND \\
\hline $\mathrm{Ni}$ & 0.000005 & 0.000002 & 0.000009 & 0.00001 & 0.000004 & 0.000018 \\
\hline $\mathrm{Pb}$ & $4.09 \mathrm{E}-7$ & $-3.252 \mathrm{E}-7$ & 0.000001 & $8.13 \mathrm{E}-7$ & $-6.488 \mathrm{E}-7$ & 0.000002 \\
\hline
\end{tabular}

Table 2. LTCR associated with HMs in well-water and borehole water in Iju and Atan.

signifies an array of risks experienced by several members of the population group ${ }^{101}$. The MCS technique offers a holistic quantitative approach of evaluating the probabilistic distribution within the boundaries of the estimation model for health risk assessment and exposure ${ }^{102}$.

\section{Conclusion}

Physicochemical and HM concentration in groundwater, geospatial variations, pollution sources and health risk assessment were examined within Iju and Atan district, South-western Nigeria. Based on the water quality results of the 108 samples analysed from both location, $100 \%$ of the well-water and $55.6 \%$ of borehole samples at Iju exceeded the WHO threshold for $\mathrm{pH}$ in water. Meanwhile, at Atan district, the $\mathrm{pH}$ violation recorded for well-water and borehole samples were $66.7 \%$ and $22.22 \%$ respectively. For both locations, lead content in the groundwater sources was relatively high. The analytical outcome revealed that $100 \%$ of well-water samples and borehole samples violated the WHO guidelines at Iju district. Whereas, Atan district recorded a $44.44 \%$ and $11.13 \% \mathrm{~Pb}$ violation in borehole and well-water samples respectively. In addition, water quality parameters such as $\mathrm{Mg}$ and Ca surpassed the WHO tolerable limits at both locations. Source identification of metals were related to geogenic and anthropogenic intrusions. The inter-parameter relationship extracted from the CA and PFA techniques revealed that the geogenic contributions were as a result of dissolutions, weathering, geological metamorphosis and leaching. However, anthropogenic contributions emanated from industrial (galvanising, foundries, textile production, tanneries) activities with the region. A further observation from the non-carcinogenic risk analysis identified potential threats from $\mathrm{Pb}$ via ingestion routes for both children and adult living within Iju district. The potential threats identified were related to both groundwater sources considered in the study, and in specific terms, the Monte Carlo simulations pinpointed that $58.40 \%$ of the adult and $84.78 \%$ of the children population are at risk on ingesting borehole water. The results also indicated that ingesting $\mathrm{Pb}$-contaminated well-water exposes $92 \%$ of the adult and $94.07 \%$ of the children population to life-threatening health scenarios. It is also necessary to mention that no potential threats from $\mathrm{Pb}$ via dermal routes were identified considering both sources and location. However, carcinogenic risk was identified for $\mathrm{Ni}$ in borehole and well-water sources within Iju.

Generally, the outcome of water analysis and health risk assessment conducted within the region, with regards to the non-carcinogenic risk posed by $\mathrm{Pb}$ ingestion, revealed that the risks are higher for children compared to adult. But, in the case of Ni carcinogenic risk, the risks were higher for adults compared to children. Therefore, this study calls for a robust water management strategy that incorporates policy implementation, recurrent water monitoring programmes, proper wastewater disposal strategy, resource accountability and effective water and wastewater treatment, so as to safeguard the lives of inhabitants within the study region.

Received: 30 January 2019; Accepted: 16 October 2019;

Published online: 04 November 2019

\section{References}

1. Kashyap, R., Verma, K. S., Uniyal, S. K. \& Bhardwaj, S. K. Geospatial distribution of metal(loid)s and human health risk assessment due to intake of contaminated groundwater around an industrial hub of northern India. Environ. Monit. Assess. 190, (2018).

2. Gündüz, O. Water Quality Perspectives in a Changing World. Water Qual. Expo. Heal. 7, 1-3 (2015).

3. Nawab, J., Khan, S. \& Xiaoping, W. Chemosphere Ecological and health risk assessment of potentially toxic elements in the major rivers of Pakistan: General population vs. Fishermen. Chemosphere 202, 154-164 (2018).

4. Giri, S. \& Singh, A. K. Spatial distribution of metal(loid)s in groundwater of a mining dominated area: recognising metal(loid) sources and assessing carcinogenic and non-carcinogenic human health risk. Int. J. Environ. Anal. Chem. 96, 1313-1330 (2016).

5. Tenebe, I. T., Ogbiye, A., Omole, D. O. \& Emenike, P. C. Estimation of longitudinal dispersion co-efficient: A review. Cogent Eng. 3, (2016). 
6. Kumar, P., Kumar, A., Kumar, C. \& Chitresh, S. Hydrogeochemical Evolution and Appraisal of Groundwater Quality in Panna District, Central India. Expo. Heal. 8, 19-30 (2016).

7. Li, P., Li, X., Meng, X., Li, M. \& Zhang, Y. Appraising Groundwater Quality and Health Risks from Contamination in a Semiarid Region of Northwest China. Expo. Heal. 8, 361-379 (2016).

8. Fallahzadeh, R. A. et al. Spatial distribution variation and probabilistic risk assessment of exposure to chromium in ground water supplies; a case study in the east of Iran. Food Chem. Toxicol. 115, 260-266 (2018).

9. Khamirchi, R. et al. Adsorption property of Br-PADAP-impregnated multiwall carbon nanotubes towards uranium and its performance in the selective separation and determination of uranium in different environmental samples. Ecotoxicol. Environ. Saf. 150, 136-143 (2018)

10. Hadley, P. W. \& Newell, C. J. Groundwater Remediation: The Next 30 Years. Ground Water 50, 669-678 (2012).

11. Chabukdhara, M., Gupta, S. K., Kotecha, Y. \& Nema, A. K. Groundwater quality in Ghaziabad district, Uttar Pradesh, India: Multivariate and health risk assessment. Chemosphere 179, 167-178 (2017).

12. Kahlon, S. K. et al. Impact of heavy metals and nanoparticles on aquatic biota. Environ. Chem. Lett. 16, 919-946 (2018)

13. Hapke, H.-J. Heavy metal transfer in the food chain to humans. Fertil. Environ. 66, 431-436 (1996).

14. Emenike, P. C., Omole, D. O., Ngene, B. U. \& Tenebe, I. T. Potentiality of agricultural adsorbent for the sequestering of metal ions from wastewater. Glob. J. Environ. Sci. Manag. 2, 411-442 (2016).

15. Jiang, Z. et al. Metal concentrations and risk assessment in water, sediment and economic fish species with various habitat preferences and trophic guilds from Lake Caizi, Southeast China. Ecotoxicol. Environ. Saf. 157, 1-8 (2018).

16. Bortey-Sam, N. et al. Health risk assessment of heavy metals and metalloid in drinking water from communities near gold mines in Tarkwa, Ghana. Environ. Monit. Assess. 187, 1-12 (2015).

17. Emenike, P. G. C., Tenebe, T. I., Omeje, M. \& Osinubi, D. S. Health risk assessment of heavy metal variability in sachet water sold in Ado-Odo Ota, South-Western Nigeria. Environ. Monit. Assess. 189, (2017).

18. Maghakyan, N., Tepanosyan, G., Belyaeva, O., Sahakyan, L. \& Saghatelyan, A. Assessment of pollution levels and human health risk of heavy metals in dust deposited on Yerevan's tree leaves (Armenia). Acta Geochim. 36, 16-26 (2017).

19. Tao, Y., Yuan, Z., Xiaona, H. \& Wei, M. Distribution and bioaccumulation of heavy metals in aquatic organisms of different trophic levels and potential health risk assessment from Taihu lake, China. Ecotoxicol. Environ. Saf. 81, 55-64 (2012).

20. Fallahzadeh, R. A., Ghaneian, M. T., Miri, M. \& Dashti, M. M. Spatial analysis and health risk assessment of heavy metals concentration in drinking water resources. Environ. Sci. Pollut. Res. 24, 24790-24802 (2017).

21. Kapaj, S., Peterson, H., Liber, K. \& Bhattacharya, P. Human health effects from chronic arsenic poisoning - A review. J. Environ. Sci. Heal. - Part A Toxic/Hazardous Subst. Environ. Eng. 41, 2399-2428 (2006).

22. Jeong, K. S. et al. Performance IQ in children is associated with blood cadmium concentration in early pregnancy. J. Trace Elem. Med. Biol. 30, 107-111 (2015).

23. Kippler, M. et al. Research | Children's Health Early-Life Cadmium Exposure and Child Development in 5-Year-Old Girls and Boys: A Cohort Study in Rural Bangladesh. Environ. Health Perspect. 120, 1462-1468 (2012).

24. Sanders, A. P., Claus Henn, B. \& Wright, R. O. Perinatal and Childhood Exposure to Cadmium, Manganese, and Metal Mixtures and Effects on Cognition and Behavior: A Review of Recent Literature. Curr. Environ. Heal. reports 2, 284-294 (2015).

25. WHO. Childhood lead poisoning. (2010).

26. Bassil, M. et al. Lead, cadmium and arsenic in human milk and their socio-demographic and lifestyle determinants in Lebanon. Chemosphere 191, 911-921 (2018).

27. Barakat, M. A. New trends in removing heavy metals from industrial wastewater. Arab. J. Chem. 4, 361-377 (2011).

28. Bellinger, D. C. Very low lead exposures and children's neurodevelopment. Curr. Opin. Pediatr. 20, 172-177 (2008).

29. Agbozu, I. E., Ekweozor, I. K. E. \& Opuene, K. Survey of heavy metals in the catfish Synodontis clarias. Int. J. Environ. Sci. Technol. 4, 93-97 (2007).

30. Shankar, S. et al. Arsenic Contamination of Groundwater: A Review of Sources, Prevalence, Health Risks, and Strategies for Mitigation, Arsenic Contamination of Groundwater: A Review of Sources, Prevalence, Health Risks, and Strategies for Mitigation. Sci. World J. 2014 2014, e304524 (2014).

31. US EPA. Environmental Protection Agency. Guidelines for carcinogen risk assessment. (2005).

32. Wiltse, J. \& Dellarco, V. L. U.S. Environmental Protection Agency guidelines for carcinogen risk assessment: Past and future. Mutat. Res. Genet. Toxicol. 365, 3-15 (1996).

33. Chen, J., Wu, H., Qian, H. \& Gao, Y. Assessing Nitrate and Fluoride Contaminants in Drinking Water and Their Health Risk of Rural Residents Living in a Semiarid Region of Northwest China. Expo. Heal. 9, 183-195 (2017).

34. Zhang, Z., Juying, L. \& Mamat, Z. Sources identification and pollution evaluation of heavy metals in the surface sediments of Bortala River, Northwest China. Ecotoxicol. Environ. Saf. 126, 94-101 (2016).

35. Emenike, P. C., Tenebe, I. T. \& Jarvis, P. Fluoride contamination in groundwater sources in Southwestern Nigeria: Assessment using multivariate statistical approach and human health risk. Ecotoxicol. Environ. Saf. 156C(2018), 391-402 (2018).

36. Khan, S. et al. Drinking water quality and human health risk in Charsadda district, Pakistan. J. Clean. Prod. 60, 93-101 (2013).

37. Alahabadi, A. et al. A comparative study on capability of different tree species in accumulating heavy metals from soil and ambient air. Chemosphere 172, 459-467 (2017).

38. Wang, G. S., Deng, Y. C. \& Lin, T. F. Cancer risk assessment from trihalomethanes in drinking water. Sci. Total Environ. 387, 86-95 (2007).

39. Qu, C., Sun, K., Wang, S., Huang, L. \& Bi, J. Monte Carlo Simulation-Based Health Risk Assessment of Heavy Metal Soil Pollution: A Case Study in the Qixia Mining Area, China. Hum. Ecol. Risk Assess. 18, 733-750 (2012).

40. Miri, M. et al. Investigation of outdoor BTEX: Concentration, variations, sources, spatial distribution, and risk assessment. Chemosphere 163, 601-609 (2016).

41. Fjeld, R. A., Eisenberg, N. A. \& Compton, K. L. Quantitative Environmental Risk Analysis for Human Health. (John Wiley \& Sons, Inc., https://doi.org/10.1002/0470096209 (2007).

42. NAS/NRC. Science and judgement in risk assessment. Committee on Risk Assessment of Hazardous Air Pollutants, National Research Council (National Acacdemy Science and the National Research Council, 1994).

43. US EPA. Guiding Principles for Monte Carlo Analysis. US EPA EPA/630/R-97/001 (1997).

44. Thompson, K. M., Burmaster, D. E. \& Crouch, E. A. C. Monte Carlo Techniques for Quantitative Uncertainty Analysis in Public Health Risk Assessments. Risk Anal. 12, 53-63 (1992).

45. Gnanachandrasamy, G. et al. Accessing groundwater quality in lower part of Nagapattinam district, Southern India: using hydrogeochemistry and GIS interpolation techniques. Appl. Water Sci. 5, 39-55 (2015).

46. Pinto, D., Shrestha, S., Babel, M. S. \& Ninsawat, S. Delineation of groundwater potential zones in the Comoro watershed, Timor Leste using GIS, remote sensing and analytic hierarchy process (AHP) technique. Appl. Water Sci. 7, 503-519 (2017).

47. Yan, X., Shi, W., Zhao, W. \& Luo, N. Mapping dustfall distribution in urban areas using remote sensing and ground spectral data. Sci. Total Environ. 506-507, 604-612 (2015).

48. Salari, A., Zakaria, M., Nielsen, C. C. \& Boyce, M. S. Quantifying tropical wetlands using field surveys, spatial statistics and remote sensing. Wetlands 34, 565-574 (2014).

49. Singh, U. K., Ramanathan, A. L. \& Subramanian, V. Groundwater chemistry and human health risk assessment in the mining region of East Singhbhum, Jharkhand, India. Chemosphere 204, 501-513 (2018). 
50. Nematollahi, M. J., Clark, M. J. R. \& Ebrahimi, P. Preliminary assessment of groundwater hydrogeochemistry within Gilan, a northern province of Iran. Environ. Monit. Assess. 190, 242 (2018).

51. Zhang, Y. et al. Hydrochemical characteristics and multivariate statistical analysis of natural water system: A case study in Kangding County, Southwestern China. Water (Switzerland) https://doi.org/10.3390/w10010080 (2018).

52. Ma, Y., Egodawatta, P., McGree, J., Liu, A. \& Goonetilleke, A. Human health risk assessment of heavy metals in urban stormwater. Sci. Total Environ. 557-558, 764-772 (2016).

53. Koki, I. B. et al. Consumption of water from ex-mining ponds in Klang Valley and Melaka, Malaysia: A health risk study. Chemosphere 195, 641-652 (2018).

54. Kayode, A. A. A., Babayemi, J. O., Abam, E. O. \& Kayode, O. T. Occurrence and health implications of high concentrations of Cadmium and Arsenic in drinking water sources in selected towns of Ogun State, South-West, Nigeria. J. Toxicol. Environ. Heal. Sci. 3, 385-391 (2011).

55. Omole, D. O., Tenebe, I. T., Emenike, C. P., Umoh, A. S. \& Badejo, A. A. Causes, impact and management of electronic wastes: Case study of some nigerian communities. ARPN. J. Eng. Appl. Sci. 10, 7876-7874 (2015).

56. Chinedu, S., Nwinyi, O., Adetayo, Y. \& Vivienne, N. Assessment of water quality in Canaanland, Ota, Southwest Nigeria. Agric. Biol. J. North Am. 2, 577-583 (2011)

57. Emenike, C. P. et al. Accessing safe drinking water in sub-Saharan Africa: Issues and challenges in South-West Nigeria. Sustain. Cities Soc. 30, 263-272 (2017).

58. Tenebe, I. T., Emenike, C. P. G. \& Daniel Chukwuka, C. Prevalence of heavy metals and computation of its associated risk in surface water consumed in Ado-Odo Ota, South-West Nigeria. Human and Ecological Risk Assessment 0, 1-23 (2018).

59. National Population Commission. Population Distribution by Sex,State,LGA\&Senatorial District. 2006 Population and Housing Census III (2010).

60. Rahaman, M. Review of the basement geology of South-Western Nigeria. In: C.A. Kogbe (Ed.) Geology of Nigeria. (Elizabethan Publishing Co; 1976).

61. Solanke, M. Spatial Pattern and Organisational Structure of Intra-Urban Trips in Ogun State, Nigeria. Ethiop. J. Environ. Stud. Manag. 8, 13-27 (2015).

62. Plazinska, A. et al. Groundwater sampling and analysis: A field guide. Geoscience Australia record (2009).

63. Ayedun, H., Taiwo, A. M., Umar, B. F., Oseni, O. A. \& Oderinde, A. A. Assessment of groundwater contamination by toxic metals in Ifo, Southwestern Nigeria. Indian J. Sci. Technol. 4, 820-823 (2011).

64. Yusuf, A., Olasehinde, A., Mboringong, M. N., Tabale, R. P. \& Daniel, E. P. Evaluation of heavy metals concentration in groundwater around Kashere and its environs, upper Benue trough, Northeastern Nigeria. Glob. J. Geol. Sci. 16, 25 (2018).

65. Amori, A., Oduntan, O., Okeyode, I. \& Ojo, S. Heavy metal concentration of groundwater deposits in Odeda region, Ogun state, Nigeria. J. Environ. Res. Manag. 4, 253-259 (2013).

66. Samsonova, V. P., Blagoveshchenskii, Y. N. \& Meshalkina, Y. L. Use of empirical Bayesian kriging for revealing heterogeneities in the distribution of organic carbon on agricultural lands. Eurasian Soil Sci. 50, 305-311 (2017).

67. Magesh, N. S., Chandrasekar, N. \& Elango, L. Trace element concentrations in the groundwater of the Tamiraparani river basin, South India: Insights from human health risk and multivariate statistical techniques. Chemosphere 185, 468-479 (2017).

68. Tiwari, A. K., Singh, A. K. \& Mahato, M. K. GIS based evaluation of fluoride contamination and assessment of fluoride exposure dose in groundwater of a district in Uttar Pradesh, India. Hum. Ecol. Risk Assess. An Int. J. 23, 56-66 (2017).

69. US EPA. Risk Assessment Guidance for Superfund Volume I Human Health Evaluation Manual (Part A). US EPA 1, (1989).

70. US EPA. Exposure Factors Handbook: 2011 Edition. U.S. Environmental Protection Agency EPA/600/R-, (2011).

71. US EPA. Integrated Risk Information System - USEPA-IRIS. U. S. Environmental Protection Agency. (2016).

72. Koki, I. B., Bayero, A. S., Umar, A. \& Yusuf, S. Health risk assessment of heavy metals in water, air, soil and fish. African J. Pure Appl. Chem. 9, 204-210 (2015).

73. World Health Organization. Guidelines for drinking-water quality. (WHO Library Cataloguing-in-Publication Data, https://doi. org/10.1016/S1462-0758(00)00006-6 (2011)

74. Nigerian Industrial Standard (NIS). Nigerian Standard for Drinking Water Quality. Standard Organisation of Nigeria: Nis-554-2015 (2015).

75. Woo, N. C. \& Choi, M. C. Arsenic and metal contamination of water resources from mining wastes in korea. Environ. Geol. 40, 305-311 (2001)

76. Adewumi, I. K., Ogbiye, A. S., Longe, E. \& Omole, D. Effect of industrial effluents on water quality of River Atuwara in Ota, Nigeria: In Urban Agriculture, Cities and Climate Change. In Urban Agriculture, Cities and Climate Change 272-280 (Cuvillier Verlag Gottingen, 2011).

77. Emenike, P. C., Nnaji, C. C. \& Tenebe, I. T. Assessment of geospatial and hydrochemical interactions of groundwater quality, southwestern Nigeria. Environ. Monit. Assess. 190, (2018).

78. Ma, Y. \& Hooda, P. S. Chromium, Nickel and Cobalt. in Trace Elements in Soils 461-479 (John Wiley \& Sons, Ltd, https://doi. org/10.1002/9781444319477.ch19 2010)

79. Pisciotta, A., Cusimano, G. \& Favara, R. Groundwater nitrate risk assessment using intrinsic vulnerability methods: A comparative study of environmental impact by intensive farming in the Mediterranean region of Sicily, Italy. J. Geochemical Explor. 156, 89-100 (2015).

80. Wendel, B. V. et al. Manganese concentrations in drinking water from villages near banana plantations with aerial mancozeb spraying in Costa Rica: Results from the Infants' Environmental Health Study (ISA) *. 215, 247-257 (2016).

81. El Alfy, M., Alharbi, T. \& Mansour, B. Integrating geochemical investigations and geospatial assessment to understand the evolutionary process of hydrochemistry and groundwater quality in arid areas. Environ. Monit. Assess. 190, (2018).

82. Rasool, A. et al. Arsenic and heavy metal contaminations in the tube well water of Punjab, Pakistan and risk assessment: A case study. Ecol. Eng. 95, 90-100 (2016).

83. Razak, N. H. A., Praveena, S. M., Aris, A. Z. \& Hashim, Z. Quality of Kelantan drinking water and knowledge, attitude and practice among the population of Pasir Mas, Malaysia. Public Health 131, 103-111 (2015).

84. Zhang, L. et al. Change of water sources reduces health risks from heavy metals via ingestion of water, soil, and rice in a riverine area, South China. Sci. Total Environ. 530-531, 163-170 (2015).

85. Cao, S. et al. Health risks from the exposure of children to $\mathrm{As}, \mathrm{Se}, \mathrm{Pb}$ and other heavy metals near the largest coking plant in China. Sci. Total Environ. 472, 1001-1009 (2014).

86. Jaishankar, M., Tseten, T., Anbalagan, N., Mathew, B. B. \& Beeregowda, K. N. Toxicity, mechanism and health effects of some heavy metals. Interdiscip. Toxicol. 7, 60-72 (2014).

87. Mara, D. \& Horan, N. The handbook of water and wastewater microbiology. (Academic, 2003)

88. World Health Organization \& International Programme for Chemical Safety. Aluminium. (World Health Organization, 1997).

89. Vardar, F. \& Ünal, M. Aluminum toxicity and resistance in higher plants. Adv. Mol. Biol. 1-12 (2007).

90. Albretsen, J. The toxicity of iron, an essential element. Vet. Med. Toxicol. Br. 82-90 https://doi.org/10.1002/bit.22085 (2006).

91. Grazuleviciene, R., Nadisauskiene, R., Buinauskiene, J. \& Grazulevicius, T. Effects of Elevated Levels of Manganese and Iron in Drinking Water on Birth Outcomes. Polish J. Environ. Stud. 18, 819-825 (2009).

92. Ayantobo, O. O., Awomeso, J. A., Oluwasanya, G. O., Bada, B. S. \& Taiwo, A. M. Non-cancer human health risk assessment from exposure to heavy metals in surface and groundwater in Igun Ijesha, Southwest Nigeria. Am. J. Environ. Sci. 10, 301-311 (2014). 
93. Maigari, A. U., Ekanem, E. O., Garba, I. H., Harami, A. \& Akan, J. C. Health Risk Assessment for Exposure to Some Selected Heavy Metals via Drinking Water from Dadinkowa Dam and River Gombe Abba in Gombe State, Northeast. World J. Anal. Chem. 4, 1-5 (2016).

94. Ogunlaja, A., Ogunlaja, O. O., Okewole, D. M. \& Morenikeji, O. A. Risk assessment and source identification of heavy metal contamination by multivariate and hazard index analyses of a pipeline vandalised area in Lagos State, Nigeria. Sci. Total Environ. 651, 2943-2952 (2019).

95. Ezemonye, L. I., Adebayo, P. O., Enuneku, A. A., Tongo, I. \& Ogbomida, E. Potential health risk consequences of heavy metal concentrations in surface water, shrimp (Macrobrachium macrobrachion) and fish (Brycinus longipinnis) from Benin River, Nigeria. Toxicol. Reports 6, 1-9 (2019).

96. Odukoya, A. M., Olobaniyi, S. B., Oluseyi, T. O. \& Adeyeye, U. A. Health risk associated with some toxic elements in surface water of Ilesha gold mine sites, southwest Nigeria. Environ. Nanotechnology, Monit. Manag. 8, 290-296 (2017).

97. Duggal, V. \& Rani, A. Carcinogenic and Non-carcinogenic Risk Assessment of Metals in Groundwater via Ingestion and Dermal Absorption Pathways for Children and Adults in Malwa Region of Punjab. J. Geol. Soc. India 92, 187-194 (2018).

98. Duggal, V., Rani, A., Mehra, R. \& Balaram, V. Risk assessment of metals from groundwater in northeast Rajasthan. J. Geol. Soc. India 90, 77-84 (2017).

99. Liang, Y. et al. Heavy Metal Contamination and Health Risk Assessment in the Vicinity of a Tailing Pond in Guangdong, China. Int. J. Environ. Res. Public Health 14, (2017).

100. Duan, B. et al. Comparison of Health Risk Assessments of Heavy Metals and As in Sewage Sludge from Wastewater Treatment Plants (WWTPs) for Adults and Children in the Urban District of Taiyuan, China. Int. J. Environ. Res. Public Health 14, (2017).

101. Fan, Q. et al. Heavy metal pollution in the Baotou section of the Yellow River, China. Chem. Speciat. Bioavailab. 20, 65-76 (2008).

102. Ozekeke, O., Uhunamure, G., Okundaye, F. \& Ejeomo, C. First Report on Probabilistic risk assessment of pesticide residues in a riverine ecosystem in South-South Nigeria. Chemosphere 231, 546-561 (2019).

\section{Acknowledgements}

With a deep sense of reference, the authors would like to appreciate the management of Covenant University for the enabling environment to conduct the research. We also appreciate the assistance of Mr Franklin Oranusi who helped in the lab work, and the anonymous reviewers for their constructive and insightful contributions.

\section{Author contributions}

PraiseGod Chidozie Emenike and Imokhai Tenebe conducted the field study, data analysis, risk analysis and wrote the manuscript. Nkpa Ogarekpe and David Omole performed the statistical analysis and revised the paper. Chidozie Nnaji did the English editing, revised the paper and addressed some specific review comments. All authors reviewed and commented on the paper.

\section{Competing interests}

The authors declare no competing interests.

\section{Additional information}

Supplementary information is available for this paper at https://doi.org/10.1038/s41598-019-52325-z.

Correspondence and requests for materials should be addressed to P.C.E.

Reprints and permissions information is available at www.nature.com/reprints.

Publisher's note Springer Nature remains neutral with regard to jurisdictional claims in published maps and institutional affiliations.

Open Access This article is licensed under a Creative Commons Attribution 4.0 International License, which permits use, sharing, adaptation, distribution and reproduction in any medium or format, as long as you give appropriate credit to the original author(s) and the source, provide a link to the Creative Commons license, and indicate if changes were made. The images or other third party material in this article are included in the article's Creative Commons license, unless indicated otherwise in a credit line to the material. If material is not included in the article's Creative Commons license and your intended use is not permitted by statutory regulation or exceeds the permitted use, you will need to obtain permission directly from the copyright holder. To view a copy of this license, visit http://creativecommons.org/licenses/by/4.0/.

(C) The Author(s) 2019 